\title{
Sharp-based, mixed carbonate-siliciclastic shallow-marine deposits (upper Miocene, Betic Cordillera, Spain): The record of ancient transgressive shelf ridges?
}

\author{
M. Poyatos-Moré a,b,*, F. García-García c , F.J. Rodríguez-Tovar ${ }^{\text {c }}$, J. Soria ${ }^{\text {d }, ~ C . ~ V i s e r a s ~}{ }^{\text {c }}$, \\ F. Pérez-Valera ${ }^{\mathrm{c}}$, I. Midtkandal ${ }^{\mathrm{b}}$ \\ a Departament de Geologia, Universitat Autònoma de Barcelona, 08193 Cerdanyola del Vallès, Barcelona, Spain \\ b Department of Geosciences, University of Oslo, Sem Sælands vei 1, 0371 Oslo, Norway \\ c Departamento de Estratigrafia y Paleontología, Universidad de Granada, Avenida de la Fuente Nueva S/N, 18071 Granada, Spain \\ d Departamento de Ciencias de la Tierra y del Medio Ambiente, Universidad de Alicante, 03690 Sant Vicent del Raspeig, Spain
}

\section{A R T I C L E I N F O}

\section{Article history:}

Received 18 October 2021

Received in revised form 28 December 2021

Accepted 28 December 2021

Available online 6 January 2022

Editor: Dr. Jasper Knight

\section{Keywords:}

Mixed carbonate-siliciclastic

Shelf ridge

Transgressive

Ravinement

Glossifungites

\begin{abstract}
A B S T R A C T
Isolated sharp-based sedimentary bodies in shelf settings can develop via the reworking of regressive deposits during transgressions. An example of these are shelf ridges, formed under a wide range of processes, and widely studied due to their high reservoir potential. However, there is still a lack of examples in mixed (carbonate-siliciclastic) successions. This study presents an outcrop example from the Upper Miocene of the Betic Cordillera (Spain), with the aim to propose a model for the development of transgressive sharp-based mixed carbonate-siliciclastic deposits, and to provide criteria to differentiate these from their regressive counterparts. The studied succession is ca. 300 m-thick, and shows a cyclic alternation of coarse and fine-grained mixed deposits. Depositional cycles start with siliciclastic-dominated offshore to offshore transition deposits, progressively replaced by lower shoreface deposits. These are abruptly truncated by sharp erosive contacts bioturbated by passively-infilled large burrows; their ichnological features allow assignation to the Glossifungites ichnofacies. These contacts are interpreted as ravinement surfaces. They are overlain by mixed carbonate-siliciclastic barforms, rich in skeletal fragments and extraclasts, and displaying large-scale cross bedding. These form several $\mathrm{m}$-thick and hundreds of $\mathrm{m}$-long depositional elements interpreted as mixed shelf ridges. These ridges formed in a fine-grained, shallow-water shelf, which occasionally received coarse siliciclastic sediment supply via gravity flows, but had a coeval offshore carbonate factory, which provided the skeletal fragments. The sharp-based, coarser-grained nature and lithological break at the base of these mixed carbonate-clastic deposits could lead to their misinterpretation as forced-regressive wedges. However, the nature of their lower contact, combined with the reworked offshore skeletal fragments, and their stacking pattern are consistent with these mixed units forming during transgression. Other studies in relatively time-equivalent deposits have demonstrated the existence of coeval regressive, coarser siliciclastic-dominated shoreline systems in relatively close localities. These evidence a complex basin configuration in the area during the upper Miocene, with the development of local depocentres and relatively narrow corridors or seaways in the Mediterranean-Atlantic connection, which could have favoured shelf reworking processes, but also promoted the development of diverse stacking patterns, reflecting the differential interaction between active tectonics and sedimentation across the region.
\end{abstract}

(C) 2022 The Author(s). Published by Elsevier B.V. This is an open access article under the CC BY-NC-ND license (http://creativecommons.org/licenses/by-nc-nd/4.0/).

\section{Introduction}

The origin of sharp-based coarse-grained sedimentary bodies isolated in fine-grained dominated offshore/shelf settings has been a matter of debate for the sedimentary community (see Snedden and Bergman, 1999; Suter and Clifton, 1999). Some studies originally

* Corresponding author at: Departament de Geologia, Universitat Autònoma de Barcelona, 08193 Cerdanyola del Vallès, Barcelona, Spain.

E-mail address: miquel.poyatos@uab.cat (M. Poyatos-Moré). interpreted them as incised valley fills or regressive shallow-marine deposits, transported onto and across the shelf during periods of abrupt lowering of relative sea level (e.g., Plint, 1988; Van Wagoner, 1991; Posamentier and Chamberlain, 1993; Bergman and Walker, 1995, 1999; Burton and Walker, 1999; MacEachern et al., 1999). Alternatively, another mechanism involves the reworking of regressive deposits by shelf processes during transgressions. This can result in the development of shelf ridges, which are relatively large-scale (several m-high, hundreds of $\mathrm{m}$-wide, few $\mathrm{km}$ long) elongate geomorphic elements observed in a wide range of either tide-, wave- or storm-dominated 

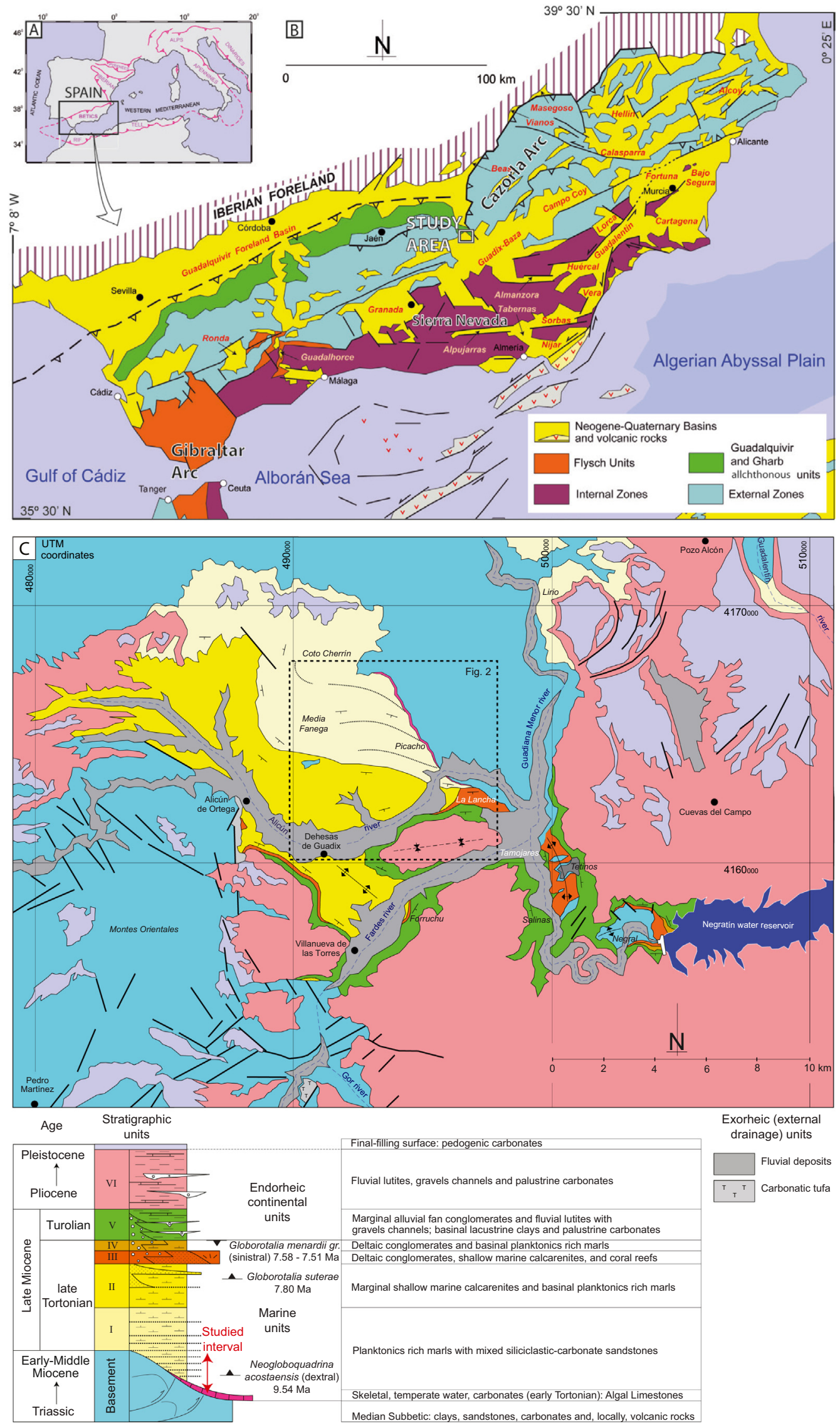

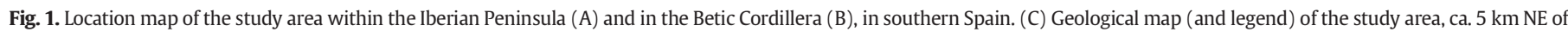
Alicún de Ortega.

Modified from Soria (1993). 
modern (e.g., Houbolt, 1968; Swift, 1975; Kenyon et al., 1981; Swift and Field, 1981; Stride, 1982; McBride and Moslow, 1991; Johnson and Baldwin, 1996; van de Meene et al., 1996; Berné et al., 1998; Snedden and Dalrymple, 1999; Dyer and Huntley, 1999; Jin and Chough, 2002; Snedden et al., 2011) and ancient shelves (e.g. Posamentier, 2002; Olariu et al., 2012; Schwarz, 2012; Messina et al., 2014; Leva-López et al., 2016; Longhitano et al., 2021). Shelf ridge deposits are commonly well sorted, relatively texturally and mineralogically mature, and with extensive and well-preserved overlying and interstratified finegrained successions, which give them potential to form good reservoirs (e.g., Posamentier, 2002; Cattaneo and Steel, 2003; Chiarella et al., 2020).

In the past few years, there has been a renewed interest in shelf ridges, with several studies that have refined previous depositional models (e.g., Snedden et al., 2011; Desjardins et al., 2012; Olariu et al., 2012; Schwarz, 2012; Messina et al., 2014; Leva-López et al., 2016; Michaud and Dalrymple, 2016; Leszczynski and Nemec, 2019; Chiarella et al., 2020). However, most of these studies are from siliciclastic-dominated systems, and there is a relative lack of studies in mixed (carbonate-siliciclastic) successions, with a few exceptions of similar deposits described in ancient straits or seaways (e.g., Longhitano et al., 2012, 2014, 2021; Rossi et al., 2017). In addition, in mixed shallow-marine settings, the carbonate factory is not necessarily located close to the coeval shoreline systems supplying the siliciclastic fraction (see Schwarz et al., 2018), which can make the correct identification of isolated shelf sedimentary bodies and their interpretation in terms of sequence stratigraphic concepts more complex.

In this study, an outcrop example from the Upper Miocene of northern Guadix Basin (Spain) is presented, with the aim to (i) characterize and discuss the origin of sharp-based mixed carbonate-siliciclastic deposits in a shallow-marine succession, (ii) propose a depositional and sequence stratigraphic model for their development in an active tectonic setting, and (iii) provide criteria to adequately differentiate them from their regressive counterparts.

\section{Geological setting}

The Betic Cordillera represents the northern branch of the arcuate Betic-Rif Alpine orogen that closes the westernmost Mediterranean Basin (Alboran Basin) across the Gibraltar Arc (Fig. 1). At the beginning of the Neogene, three major tectono-palaeogeographic domains formed and delimited the Betic Cordillera: (1) a fold-and-thrust belt (External Zones or South Iberian Palaeomargin), (2) a thrust stack of metamorphic nappe complexes (Internal Zones or Alboran Domain), and (3) allochthonous deposits (Flysch or Gibraltar Units) (Balanyá and García-Dueñas, 1987). Westward displacement of the Internal Zones configured two major N-S arcuate thrust systems (Gibraltar and Cazorla Arcs) connected by E-W transfer fault zones (Pérez-Valera et al., 2017). This structural configuration controlled the creation of high-subsidence depocentres during the Atlantic-Mediterranean connection through the Betic corridor (Martín et al., 2009; Hüsing et al., 2010; Reolid et al., 2012). One of these depocentres is found in the Guadix Basin, at the central sector of the Betic Cordillera, which preserves a few hundred-m thick Tortonian marine succession (Fernández et al., 1996; Soria et al., 1999).

The study area is located in the northern part of the Guadix Basin (Fig. 1). Here the sedimentary infill covers the period from the Tortonian to the Quaternary and is composed of six depositional sequences (referred to as Units I-VI, after Fernández et al., 1996, Fig. 1C), separated by regional unconformities or correlative conformities representing major tectonic and/or eustatic events (Fernández et al., 1996; Soria et al., 1999; García-García et al., 2009). This study is focused on the lowermost part of the succession, with more than $1 \mathrm{~km}-$ thick Tortonian marine deposits forming the first three depositional sequences, which are (from base to top): Unit I, the objective of this study, formed by offshore to nearshore silty marlstones, sandstones, calcarenites and conglomerates, and defined by Neogloboquadrina acostaensis to $N$. humerosa planktonic foraminifera subzones (Soria, 1993); Unit II, dominated by offshore marine marlstones interbedded with occasional dm-thick sandstones, and defined by Globorotalia suterae planktonic foraminifera subzone; and Unit III, represented by nearshore cross-stratified mixed siliciclastic-carbonate deposits and large-scale cross-bedded conglomerates (Soria, 1993; Soria et al., 2003; Reolid et al., 2012).

The succession crops out in a regional monoclinal structure with strata consistently dipping to the S-SW (Fig. 1). This overall disposition is altered by local syn- and post-depositional faults and associated internal angular unconformities, although these are not necessarily associated with major facies changes. The strata also show an abrupt onlap termination against a highly-tilted lower Miocene algal limestone unit on top of the basement, formed by Mesozoic rocks from the External Zone (Soria, 1993; Pérez-Valera et al., 2017) (Fig. 2).

\section{Dataset and methods}

This study is based on the detailed analysis of a 304 m-thick outcrop stratigraphic section (Fig. 3), which was measured at cm-scale. Field data were obtained using conventional methodology of logging and describing sedimentary rocks, collecting information about lithology (texture and composition), sedimentary structures, ichnological features and composition, bioturbation index (BI of Taylor and Goldring, 1993), orientation of palaeocurrent indicators, scale and geometry of both stratification and sedimentary bodies, types of contacts and sample collection $(n=7)$ for thin section and hand-specimen analysis for each type of deposit. Once measured, the succession was characterized by defining sedimentary facies associations and vertical stratigraphic trends.

\section{Results}

\subsection{Facies analysis}

The succession shows a recurrent alternation of coarse and finegrained mixed carbonate/siliciclastic deposits (Fig. 3), with dominantly silty marlstones and marly sandstones alternating with $\mathrm{m}$-scale, sharpbased and laterally-continuous mixed siliciclastic-carbonate medium to coarse-grained packages. A detailed facies analysis has allowed the definition of 7 facies associations (FA 1-7), which are described below and summarized in Table 1.

\subsection{Grey structureless marlstones (FA1-offshore)}

This facies association is composed of whitish grey, structureless to faintly laminated marlstones (Fig. 4A, B). Despite the lack of structures, subtle grain-size changes occur within mm-scale beds, and bedding contacts are roughly parallel where visible. Thin section analysis reveals that these deposits are dominated by quartz grains and planktonic foraminifera, floating inside the muddy matrix that occupies more than $15 \%$ of the rock (Fig. 5A). Other studies have also described sponge spicules and radiolarian in the same deposits (Soria, 1993). Beds are $\mathrm{mm}$ to cmthick, but packages can reach several metres in thickness (Fig. 6). Large accumulations of well-preserved bivalves are locally observed in these deposits in the lower part of the section. Bioturbation is absent to low (BI 0-2). Regional mapping reveals that they form laterally extensive units, which can be followed for several km (Figs. 2, 3). Scattered thinbedded (up to $10 \mathrm{~cm}$-thick), normally-graded muddy sandstone beds are observed within the mudstone successions, some with erosive bases and rippled tops, and up to moderately bioturbated (BI 0-3).

\subsubsection{Interpretation}

The dominant fine-grained nature of these deposits, combined with the microfossil content (mainly planktonic foraminifera) and relatively low bioturbation index, suggests that they accumulated in a relatively 


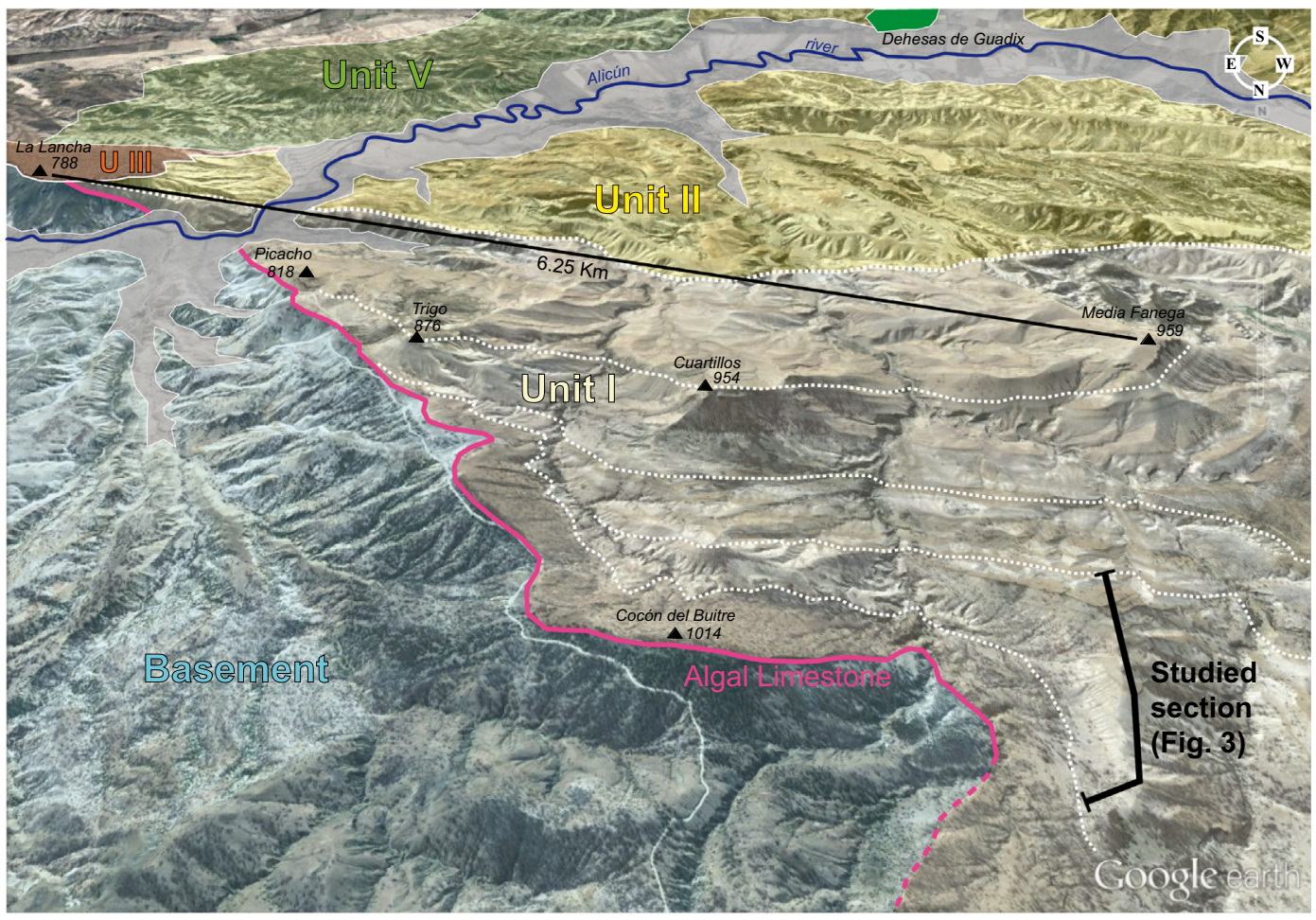

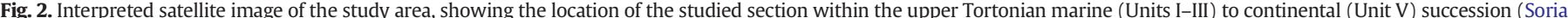

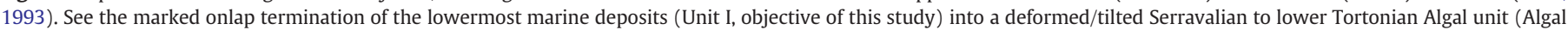
Limestone), on top of a basement formed by Mesozoic to Lower Miocene rocks from the External Zone (Pérez-Valera et al., 2017).
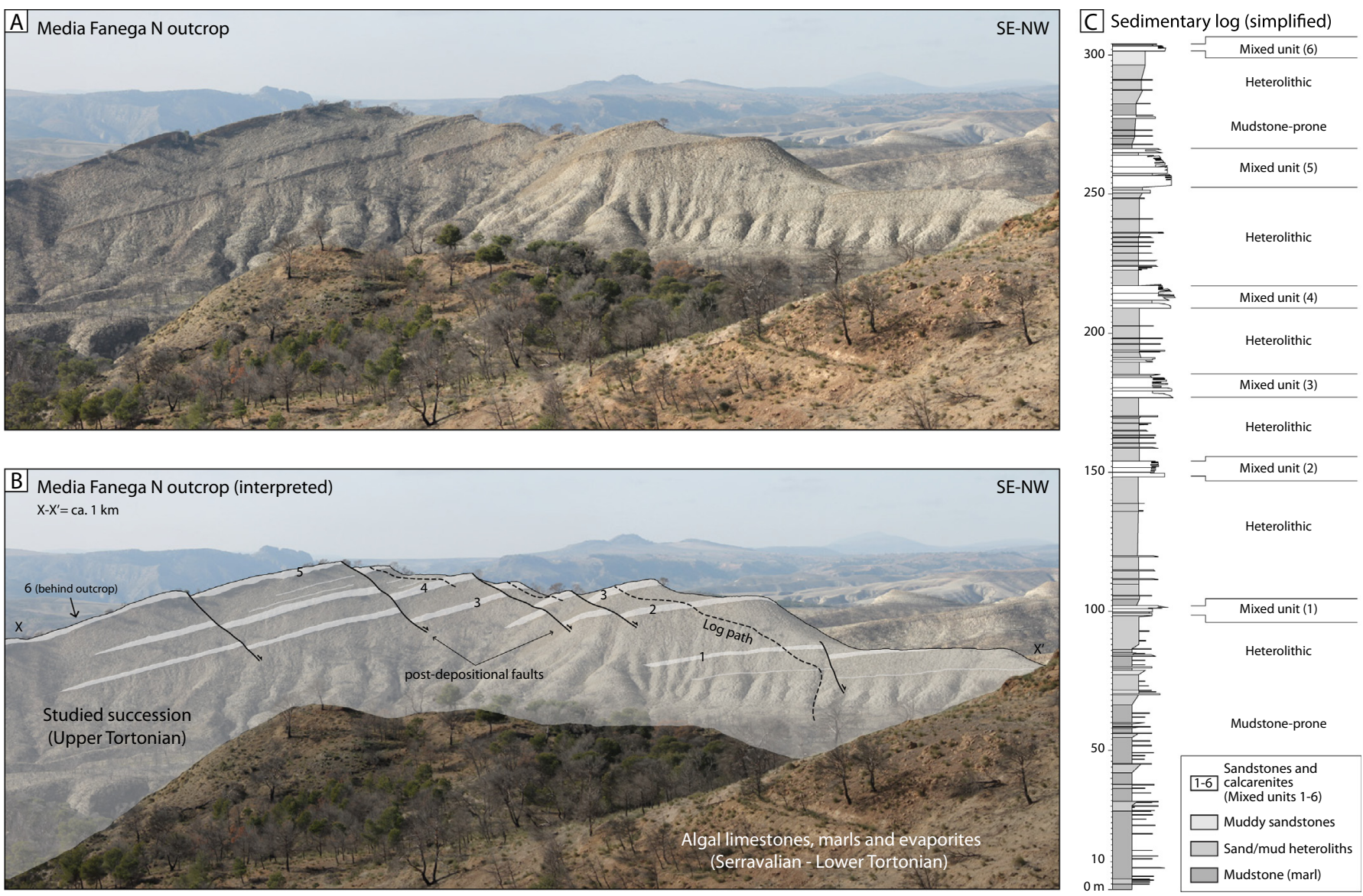

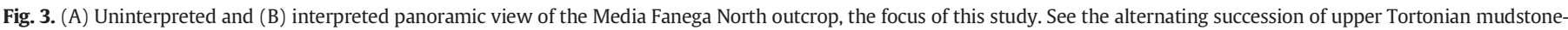

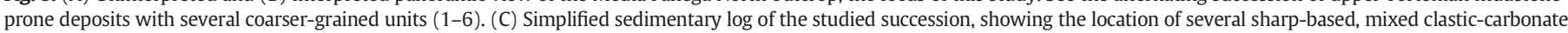
units (mixed units 1-6), within a succession dominated by muddy sandstone and heterolithic deposits. 
Table 1

Summary of the main characteristics of the facies associations recognized in this study.

\begin{tabular}{|c|c|c|c|c|c|c|c|c|c|}
\hline Code & Texture & Structures & Thickness & Fossil content & Bioturbation & Trace fossils & Other & Interpretation & Environment \\
\hline FA1 & $\begin{array}{l}\text { Whitish grey } \\
\text { mudstones. }\end{array}$ & \begin{tabular}{|l|} 
Massive to crudely \\
laminated. Subtle grain- \\
size changes, diffuse \\
bedding contacts, \\
roughly parallel.
\end{tabular} & $\begin{array}{l}\text { Normally } \mathrm{mm} \text {-scale } \\
\text { beds. Form } \mathrm{cm} \text { - to } \\
\text { several } \mathrm{m} \text {-thick } \\
\text { packages. }\end{array}$ & $\begin{array}{l}\text { Planktonic organisms: } \\
\text { foraminifera, sponge spicules and } \\
\text { radiolaria. Locally large } \\
\text { accummulation of well-preserved } \\
\text { bivalves. }\end{array}$ & $\begin{array}{l}\text { Absent to low (BI } 0 \\
1) \text {. }\end{array}$ & & $\begin{array}{l}\text { Form regionally-extensive units. Ocasional, thin- } \\
\text { bedded (up to } 10 \mathrm{~cm} \text {-thick), normally graded muddy } \\
\text { sandstone beds. }\end{array}$ & $\begin{array}{l}\text { Distal offshore setting, below storm wave base, } \\
\text { with occasional siliciclastic input by low-density } \\
\text { turbidity currents and hemipelagic suspension } \\
\text { settling. }\end{array}$ & Offshore \\
\hline FA2 & $\begin{array}{l}\text { Grey sandy } \\
\text { mudstones, with } \\
\text { subordinate very } \\
\text { fine to fine- } \\
\text { grained } \\
\text { sandstones. }\end{array}$ & \begin{tabular}{|l|} 
Typically massive (sandy \\
mudstones), occasional \\
ripples and HCS \\
(sandstones).
\end{tabular} & \begin{tabular}{|l|}
$8-40$ m-thick \\
packages (sandy \\
mudstones), 5 to 40 \\
cm-thick beds \\
(sandstones).
\end{tabular} & Fragments of bivalves. & \begin{tabular}{|l|} 
Absent to \\
moderate (BI 0-3). \\
Vertical or \\
horizontal traces, \\
increase from top \\
down.
\end{tabular} & Scolicia. & $\begin{array}{l}\text { Sandstone beds traceable for } 100 \text { 's of } \mathrm{m} \text {. Tabular or } \\
\text { lens shaped, with erosive and/or loaded bases, and } \\
\text { normally graded. Abundance of organic matter, } \\
\text { bioclasts and extraclasts (mainly quartz). Soft- } \\
\text { sediment deformation common. }\end{array}$ & $\begin{array}{l}\text { Offshore transition setting, above storm-wave. } \\
\text { Lower proportion (or preservation) of storm } \\
\text { deposits than lower shoreface deposits. }\end{array}$ & $\begin{array}{l}\text { Offshore } \\
\text { transition }\end{array}$ \\
\hline FA3 & $\begin{array}{l}\text { Grey sandy } \\
\text { mudstones to } \\
\text { muddy } \\
\text { sandstones. }\end{array}$ & $\begin{array}{l}\text { Wavy bedding and } \\
\text { symmetrical ripple } \\
\text { lamination. Occasional } \\
\text { hummocky, low-angle, } \\
\text { tangential cross- } \\
\text { stratification. }\end{array}$ & $\begin{array}{l}\text { 3-19 m-thick } \\
\text { packages, isolated } \\
\text { cm-thick beds. }\end{array}$ & - & $\begin{array}{l}\text { Moderate to high } \\
\text { (BI 2-4). }\end{array}$ & & $\begin{array}{l}\text { Isolated cm-thick beds can show soft sediment } \\
\text { deformation. Paleocurrents from cross-stratified } \\
\text { foresets point dominantly towards the S-SE. Deposits } \\
\text { stack forming corsening-up successions. }\end{array}$ & $\begin{array}{l}\text { Dominantly low-energy lower shoreface setting. } \\
\text { Occasional appearance of combined flow } \\
\text { deposits during storms. }\end{array}$ & Lower shoreface \\
\hline FA4 & $\begin{array}{l}\text { Yellow medium to } \\
\text { very coarse- } \\
\text { grained, bioclastic } \\
\text { calcarenites. }\end{array}$ & Structureless. & $\begin{array}{l}60 \text { to } 250 \mathrm{~cm} \text {-thick } \\
\text { beds. }\end{array}$ & \begin{tabular}{|l} 
Abundant skeletal fragments \\
(bivalves, bryozoans, red algae, \\
echinoids), poorly-organized.
\end{tabular} & $\begin{array}{l}\text { Moderate to high } \\
\text { (BI 3-4). Highly- } \\
\text { bioturbated base. }\end{array}$ & $\begin{array}{l}\text { Thalassinoides, } \\
\text { Rhizocorallium, } \\
\text { Skolithos, } \\
\text { Bergaueria. }\end{array}$ & $\begin{array}{l}\text { Undeformed and sharp-walled burrows, penetrating } \\
\text { up to } 20 \mathrm{~cm} \text { into underlying deposits, and passively } \\
\text { infilled. Organic matter, carbonaceous debris and } \\
\text { extraclasts (quartz, volcanics). }\end{array}$ & $\begin{array}{l}\text { Transgressive deposits resulting from } \\
\text { remobilization of coeval carbonate factory, } \\
\text { mixed with ravinement erosion of underlying } \\
\text { siliciclastic deposits. }\end{array}$ & $\begin{array}{l}\text { Transgressive } \\
\text { deposits }\end{array}$ \\
\hline FA5 & $\begin{array}{l}\text { Yellow fine to } \\
\text { coarse-grained } \\
\text { bioclastic } \\
\text { calcarenites. }\end{array}$ & \begin{tabular}{|l|} 
Structureless to large- \\
scale, bidirectional \\
sigmoidal cross-bedding.
\end{tabular} & $\begin{array}{l}70-150 \mathrm{~cm} \text {-thick } \\
\text { beds, grouped in up } \\
\text { to } 6 \mathrm{~m} \text {-thick bedsets }\end{array}$ & $\begin{array}{l}\text { Abundant skeletal fragments } \\
\text { (bivalves, bryozoans, red algae, } \\
\text { echinoids). }\end{array}$ & $\begin{array}{l}\text { Moderate to high } \\
\text { (Bl 3-5). }\end{array}$ & \begin{tabular}{|l} 
Planolites, \\
Thalassinoides, \\
Ophiomorpha, \\
Bichordites, \\
Scolicia.
\end{tabular} & $\begin{array}{l}\text { Organic matter, carbonaceous debris and extraclasts } \\
\text { (quartz, volcanics). Relatively sharp top, occasionally } \\
\text { cemented and concretionary. Loaded bases } \\
\text { common. Deposits stacked in single or multiple sets, } \\
\text { with bidirectional accretion towards S-N. }\end{array}$ & $\begin{array}{l}\text { Mixed barforms resulting from the migration of } \\
\text { subaqueous bedforms and reworking of } \\
\text { ravinement deposits by shelf processes (i.e. tides } \\
\text { or storms). }\end{array}$ & Mixed bars \\
\hline FA6 & \begin{tabular}{|l} 
Grey-yellow very \\
fine to fine- \\
grained \\
sandstones.
\end{tabular} & Structurless. & $\begin{array}{l}\text { Up to } 20 \mathrm{~cm} \text {-thick } \\
\text { beds. Packages up } \\
\text { to } 1.5 \mathrm{~m} \text {-thick. }\end{array}$ & Mainly fragments of bivalves. & High (B| 5-6). & Scolicia. & $\begin{array}{l}\text { Highly cemented, concretionary horizons, with } \\
\text { ocasional glauconite. }\end{array}$ & $\begin{array}{l}\text { Condensed deposits, formed under low energy, } \\
\text { low sedimentation rate conditions, associated } \\
\text { with regional flooding events. }\end{array}$ & $\begin{array}{l}\text { Condensed } \\
\text { deposits }\end{array}$ \\
\hline FA7 & \begin{tabular}{|l|} 
Bioclastic, medium \\
to coarse-grained \\
pebbly \\
sandstones.
\end{tabular} & $\begin{array}{l}\text { Structurless to subtle } \\
\text { large-scale cross- } \\
\text { bedding. }\end{array}$ & 5 m-thick package. & $\begin{array}{l}\text { Skeletal fragments (bivalves, } \\
\text { bryozoans, red algae). }\end{array}$ & $\begin{array}{l}\text { Low to moderate } \\
\text { (BI 1-3). }\end{array}$ & & $\begin{array}{l}\text { Concave-up erosive base. Organic matter, } \\
\text { carbonaceous debris and large (up to several cm- } \\
\text { long) extraclasts (quartz, volcanics). }\end{array}$ & $\begin{array}{l}\text { Subaqueous channel/gulley fills with a regressive } \\
\text { surface of marine erosion at the base. }\end{array}$ & Channel-fill \\
\hline
\end{tabular}



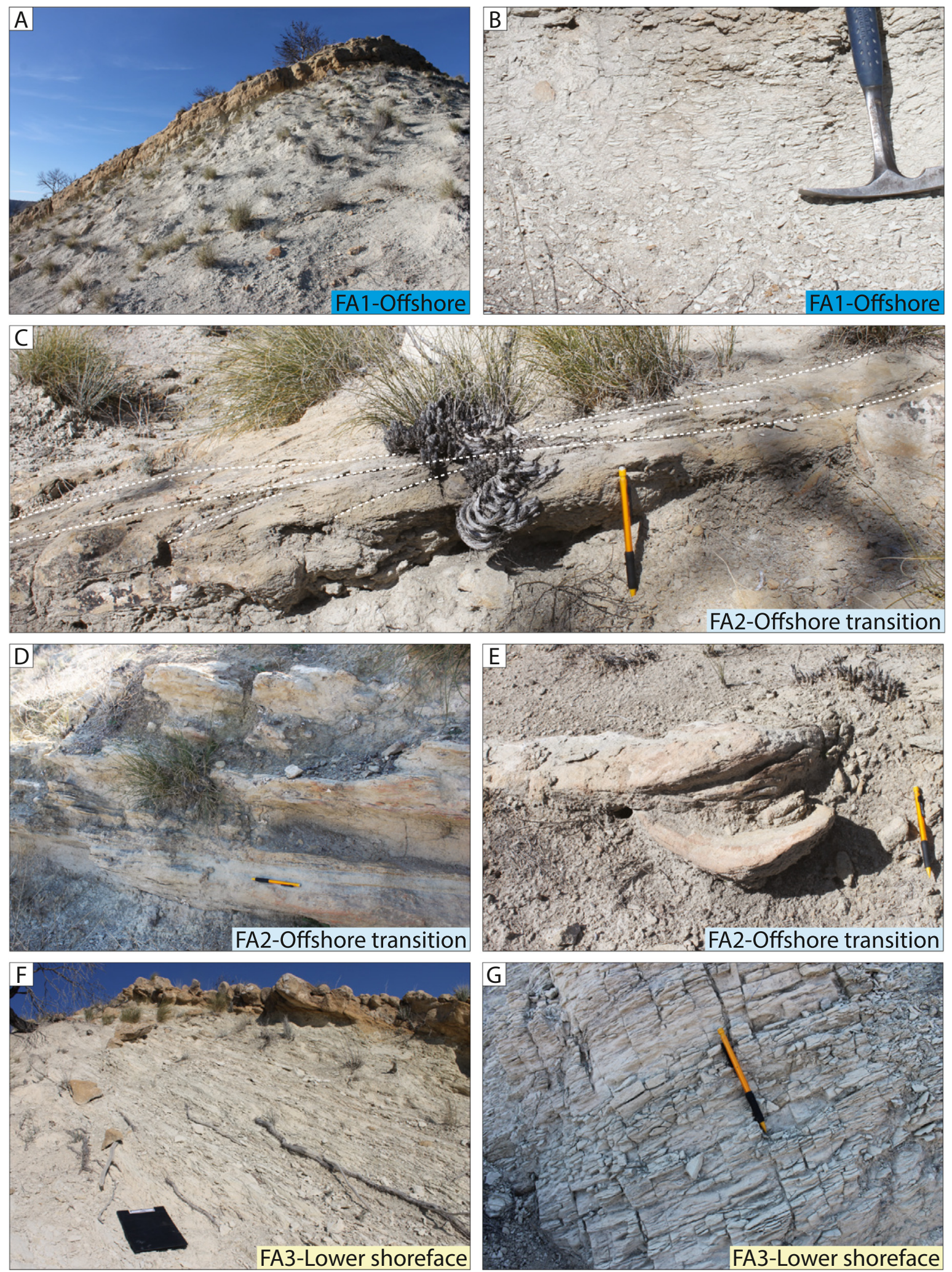

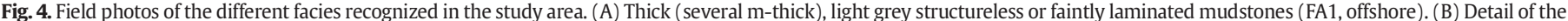

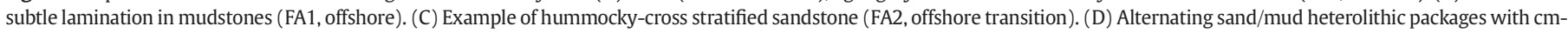

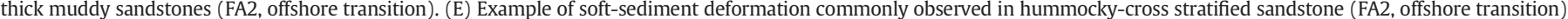

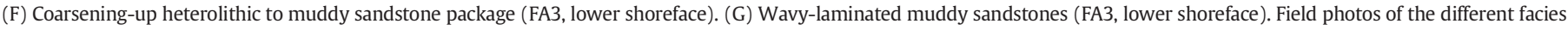

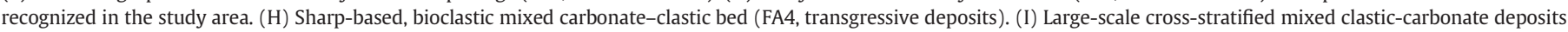

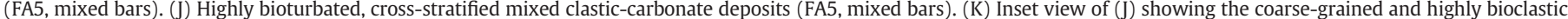

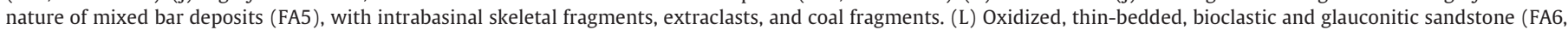

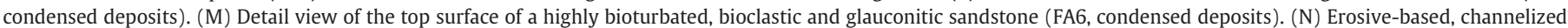

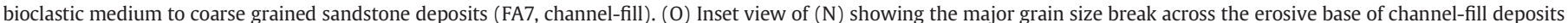
(FA7), cutting into lower shoreface muddy sandstones (FA3). 

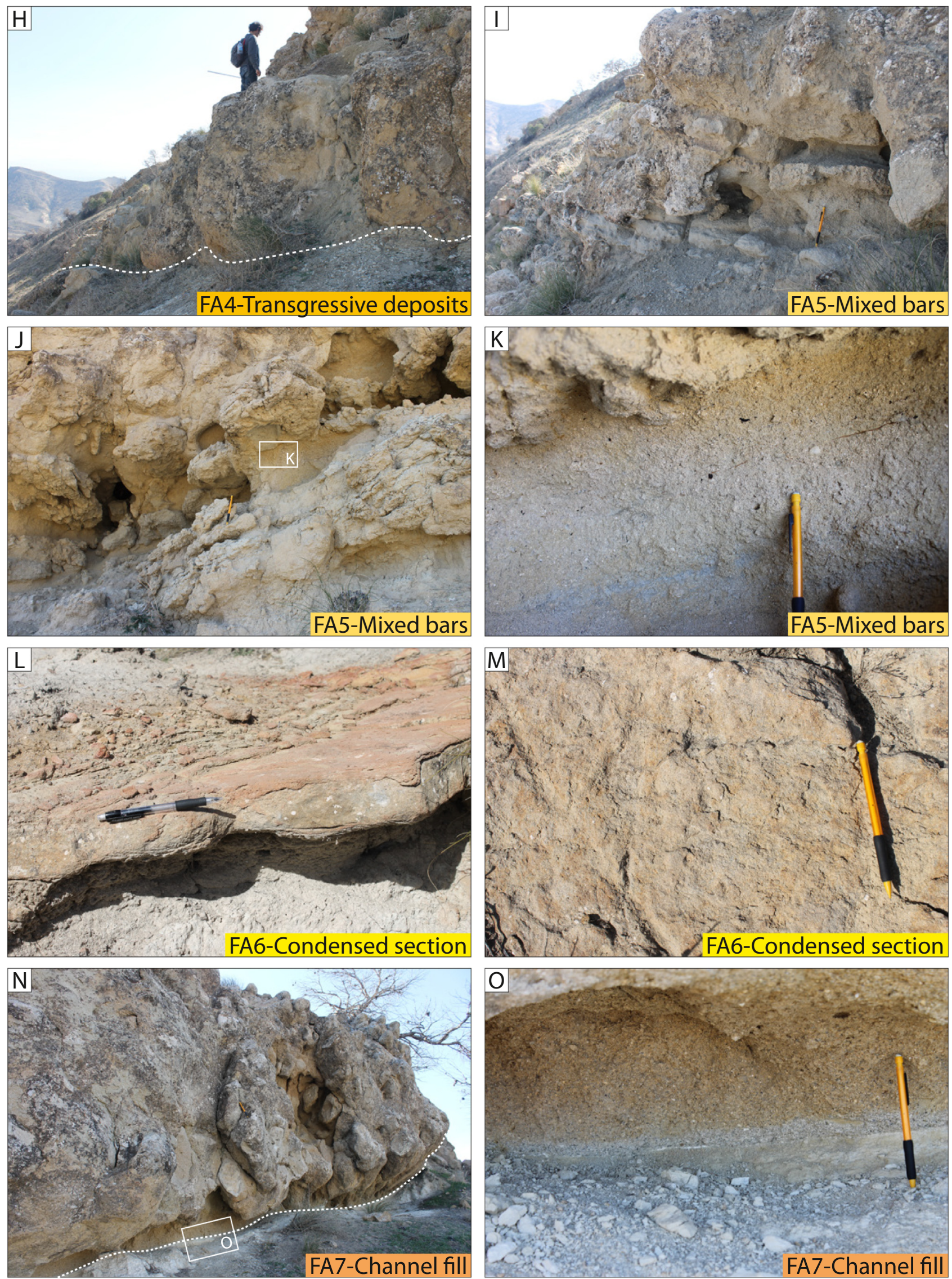

Fig. 4 (continued) 

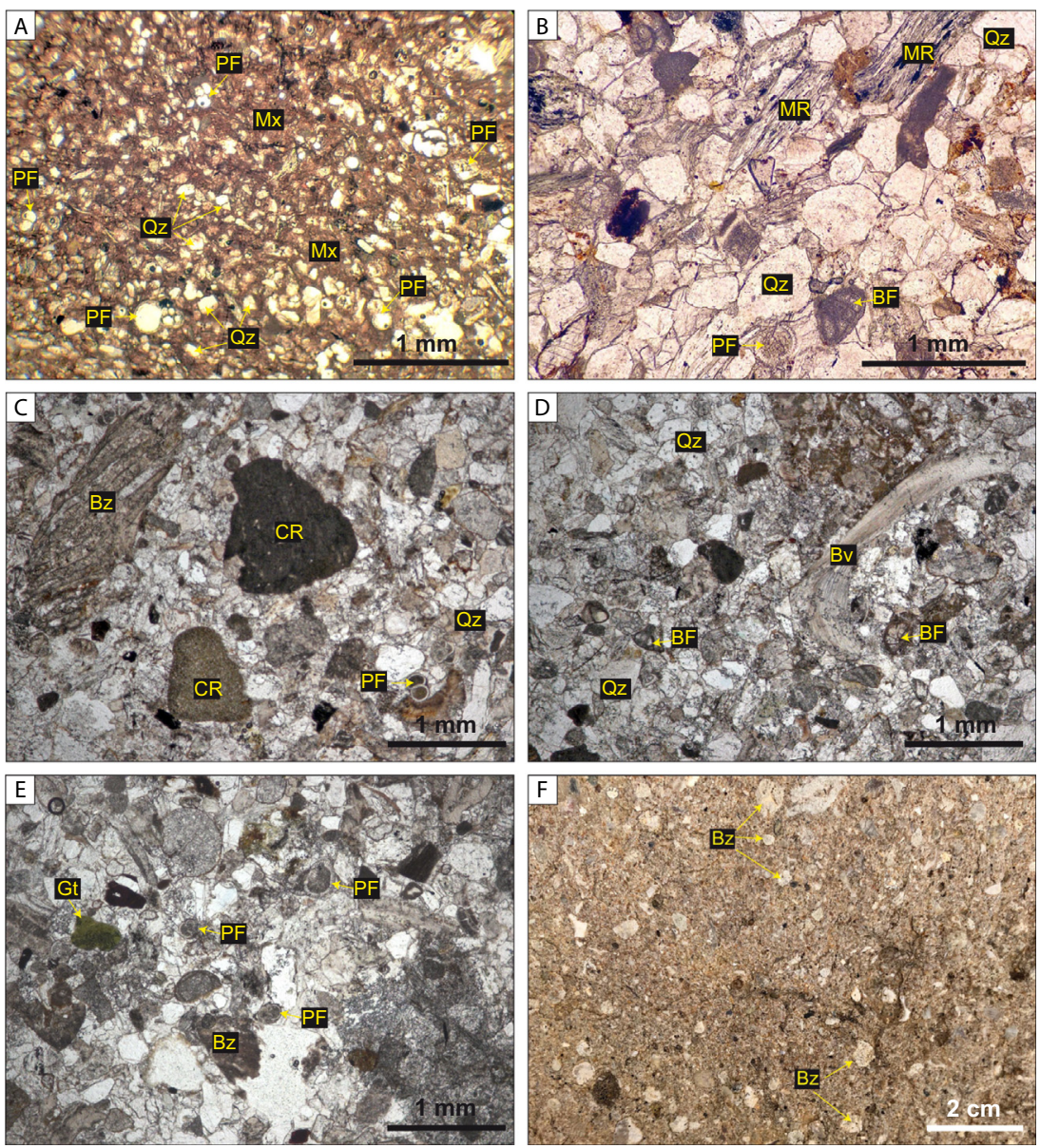

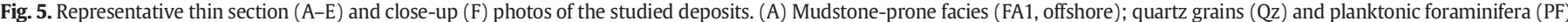

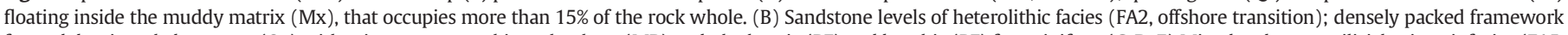

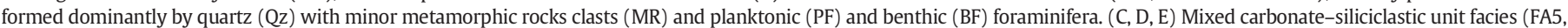

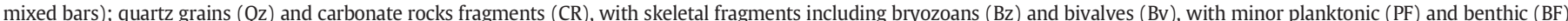

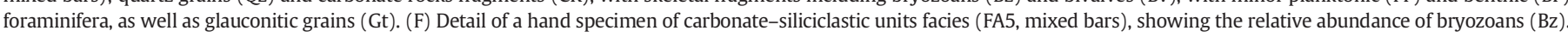

distal depositional setting, below storm wave base, with dominant lowenergy processes such as hemipelagic suspension settling (Birgenheier et al., 2017). Minor presence of normally-graded sandstone thin beds suggests that this offshore setting received occasional coarse-grained siliciclastic supply via low-density turbidity currents (e.g., hyperpycnal flows) (Bhattacharya and MacEachern, 2009; Harazim and McIlroy, 2015).

\subsection{Heterolithic sandstone/marlstone packages (FA2 - offshore transition)}

This facies association is composed of grey laminated sandy marlstones and sandstone/marlstone heterolithic packages, interbedded with 5 to $40 \mathrm{~cm}$-thick isolated fine to coarse-grained sandstone beds (Fig. 4D). These beds are tabular or lens shaped, with erosive and/or deformed bases (e.g., load casts), normal grading and rippled tops, hummocky-cross stratification and common soft-sediment deformation (Fig. 4C, E). Naked-eye analysis of sandstone beds reveals abundant extraclasts (mainly quartz), organic matter and bioclasts. Thin section analysis confirms that they are dominated by quartz grains, with minor metamorphic rock fragments and planktonic and benthic foraminifera (Fig. 5B). Tool marks (mainly flutes) and foresets show palaeocurrents ranging to the SW-NW (Fig. 6). Sandstone beds can be up to moderately bioturbated (BI 0-3), with vertical or horizontal traces at the top surface (Fig. 8A). Packages range from 8 to $40 \mathrm{~m}$ in thickness (Fig. 6). The tops of these packages can be gradational to overlying lower shoreface deposits (FA3) or be abruptly truncated by transgressive deposits (FA4) (Fig. 6).

\subsubsection{Interpretation}

The heterolithic and coarser-grained character of these facies, together with the fossil content (planktonic and benthic foraminifera) and the common appearance of combined-flow structures suggests that these facies accumulated in an offshore transition setting, above storm-wave base (Dott and Bourgois, 1982; Duke, 1985; Duke et al., 1991; Dumas et al., 2005). Coarse-grained sands were transported by seaward low to high-density turbidity currents (e.g., hyperpycnal flows), and were partly reworked by storms (e.g., Myrow et al., 2002; Pattison et al., 2007; Lamb et al., 2008; Steel et al., 2018; Jelby et al., 2020).

4.4. Wavy-laminated sandy mudstones to muddy sandstones (FA-3 - lower shoreface)

This facies association is composed of grey laminated sandy mudstones to muddy sandstones, with wavy bedding and symmetrical ripple cross-lamination (Fig. $4 \mathrm{~F}, \mathrm{G}$ ), and isolated $\mathrm{cm}$-thick beds with low-angle, hummocky and tangential/sigmoidal cross stratification and soft sediment deformation. Palaeocurrents from crossstratification foresets, where observed, point dominantly towards the S-SE. Packages are 3 to $19 \mathrm{~m}$-thick, and tend to stack forming coarsening-up successions (Fig. 6). They generally display a gradational lower contact from underlying offshore transition deposits (FA2), and are conformably overlain by condensed deposits (FA7) or abruptly truncated by transgressive (FA4) or channel-fill (FA7) deposits (Fig. 6). 


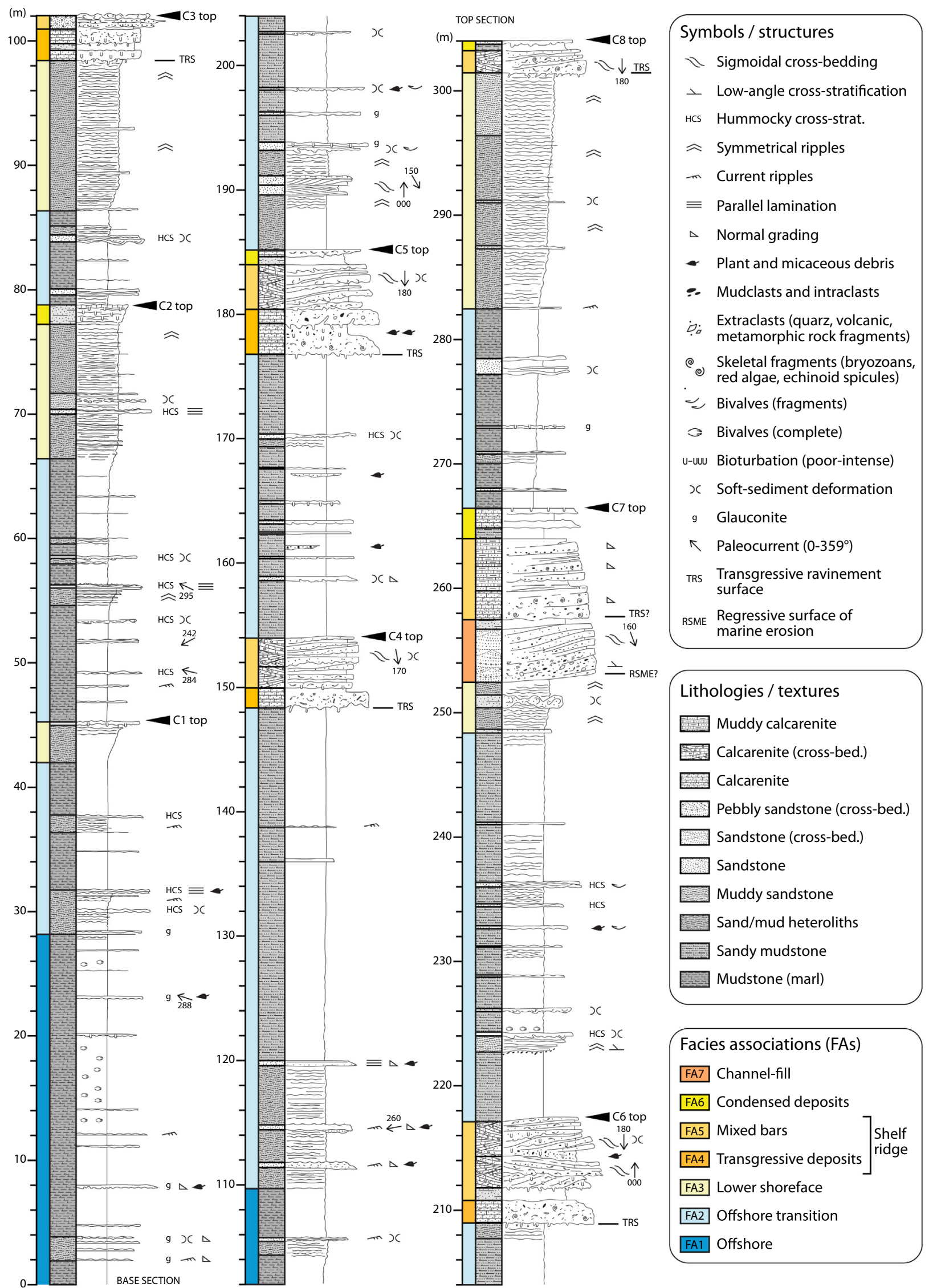

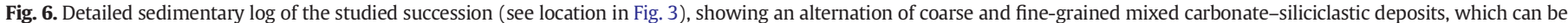
subdivided in at least 8 cycles (C1-C8). 


\subsubsection{Interpretation}

The sandy but fine-grained and thin-bedded nature of the deposits, common presence of wavy bedding and symmetrical ripples, and occasional appearance of thick sandstone beds with larger-scale combinedflow structures suggest that these deposits accumulated in a dominantly low-energy lower shoreface setting (Walker and Plint, 1992; Yang et al., 2005; Dumas and Arnott, 2006).

\subsection{Structureless bioclastic calcarenites (FA4 - transgressive deposits)}

This facies association is composed by yellow medium to very coarse-grained, structureless bioclastic calcarenites (Fig. 4H). Beds are 60 to $250 \mathrm{~cm}$-thick and moderately to highly bioturbated (BI 3-5) (Fig. 6). They have a prominent sharp, erosive highly bioturbated base, with vertical, sub-vertical and oblique J-shaped burrows and shallow cylindrical rounded structures, as well as circular sections and horizontal, branched, forms. Most traces can be assigned to Thalassinoides, but with local presence of Rhizocorallium, Skolithos and Bergaueria. Burrows are undeformed and characterized by sharp contacts, showing, in some cases a penetration depth up to around $20 \mathrm{~cm}$ into the underlying deposits, and are passively infilled by mixed carbonate-clastic sediment (Fig. 8B, C). This includes abundant skeletal fragments (dominantly from bivalves and bryozoans, and minor red algae and echinoids), organic matter, coal fragments and extraclasts (quartz and volcanic-rock fragments), in a relatively poorly-sorted organization. Normallygraded bed tops occur. These deposits can be laterally discontinuous, but they are commonly found abruptly truncating offshore transition (FA2) or lower shoreface (FA3) deposits, and overlain by mixed bar (FA5) or condensed (FA6) deposits (Figs. 6, 7).

\subsubsection{Interpretation}

The ichnological features found at the base of these deposits allow assignation to the Glossifungites ichnofacies, developed into compacted, semi-lithified substrates (Seilacher, 1967). This firmground ichnofacies has been used extensively in the identification of omission surfaces and the identification and interpretation of transgressive surfaces (MacEachern et al., 1992, 1999; Bann et al., 2004; Rodríguez-Tovar et al., 2007). The contacts are therefore interpreted as transgressive surfaces, although evidence is not conclusive to associate them to either wave or tidal ravinement processes (see Cattaneo and Steel, 2003).
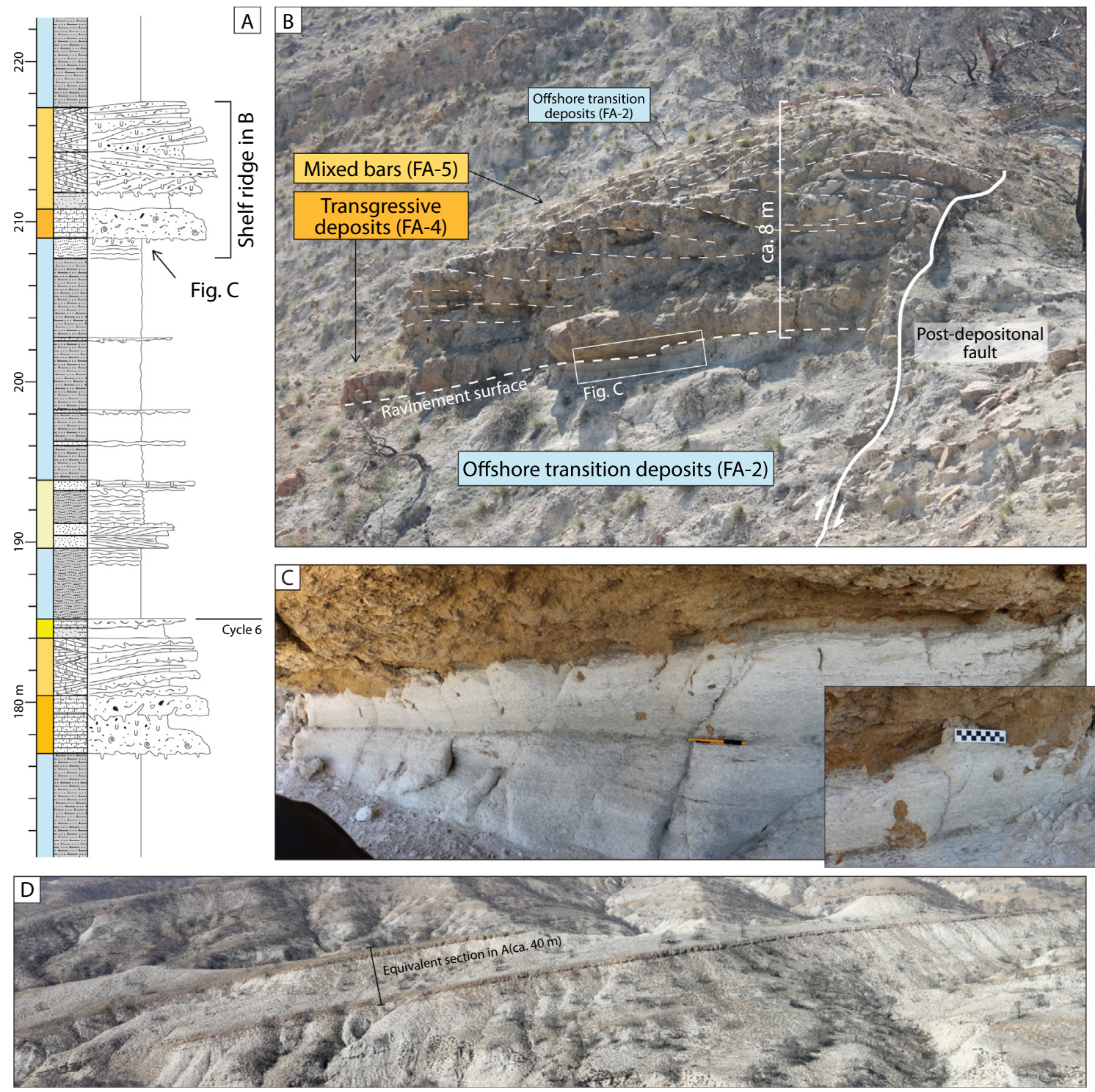

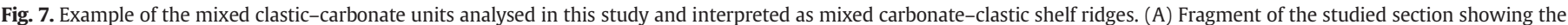

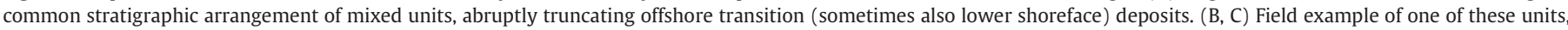

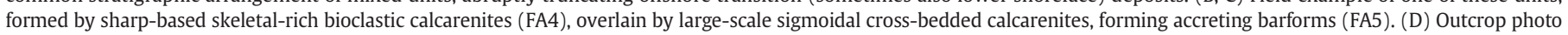
highlighting the sharp-based, sharp-topped nature of the mixed clastic-carbonate units, as well as their significant lateral extension (outcrop length $=$ ca. $1 \mathrm{~km})$. 
The poorly-sorted and bioclastic-rich deposits immediately overlying these surfaces are consequently interpreted as transgressive deposits (Zecchin et al., 2019), resulting from the remobilization of a coeval carbonate factory, mixed with the erosion of underlying offshore transition (FA2) and lower shoreface (FA3) deposits. However, the transgressive reworking of coarser-grained, forced-regressive sandstone wedges located farther seaward cannot be ruled out.

\subsection{Sigmoidal cross-bedded bioclastic calcarenites (FA5 - mixed bars)}

This facies association is composed of yellow fine to coarse-grained, cross-bedded bioclastic calcarenites (Fig. 4I, J). Beds commonly have soft-sediment deformed bases, and are arranged in stacked dominantly single (locally multiple) sets of large-scale sigmoidal cross-bedding, forming up to $8 \mathrm{~m}$-thick barforms (Figs. 6, 7), with relatively sharp tops, occasionally highly cemented and concretionary. They have abundant skeletal fragments (dominantly from bivalves and bryozoans, and minor red algae and echinoids), benthic and planktonic foraminifera, glauconitic grains, organic matter, coal fragment debris and extraclasts (Fig. 4K). Thin section and hand-specimen analysis reveals the average grain composition is $70 \%$ clastic grains (30\% quartz, $40 \%$ lithic fragments: metamorphic, volcanic and limestone-rock fragments), 10\% bioclasts and 20\% siliciclastic matrix (Fig. 5C-F). Bars show bidirectional accretion directions ranging towards the $\mathrm{S}$ and $\mathrm{N}$, although southward accretion dominates (Figs. 6, 7). Beds are moderately to highly bioturbated (BI 3-5), with traces including dominant Planolites, welldeveloped Thalassinoides structures, vertical Ophiomorpha shafts, and local Bichordites/Scolicia (Fig. 8D-F).

\subsubsection{Interpretation}

These deposits are interpreted as mixed siliciclastic-carbonate barforms, resulting from the reworking of a coeval carbonate factory, together with the underlying offshore transition (FA2) and lower shoreface (FA3), but also transgressive deposits (FA4), accumulated
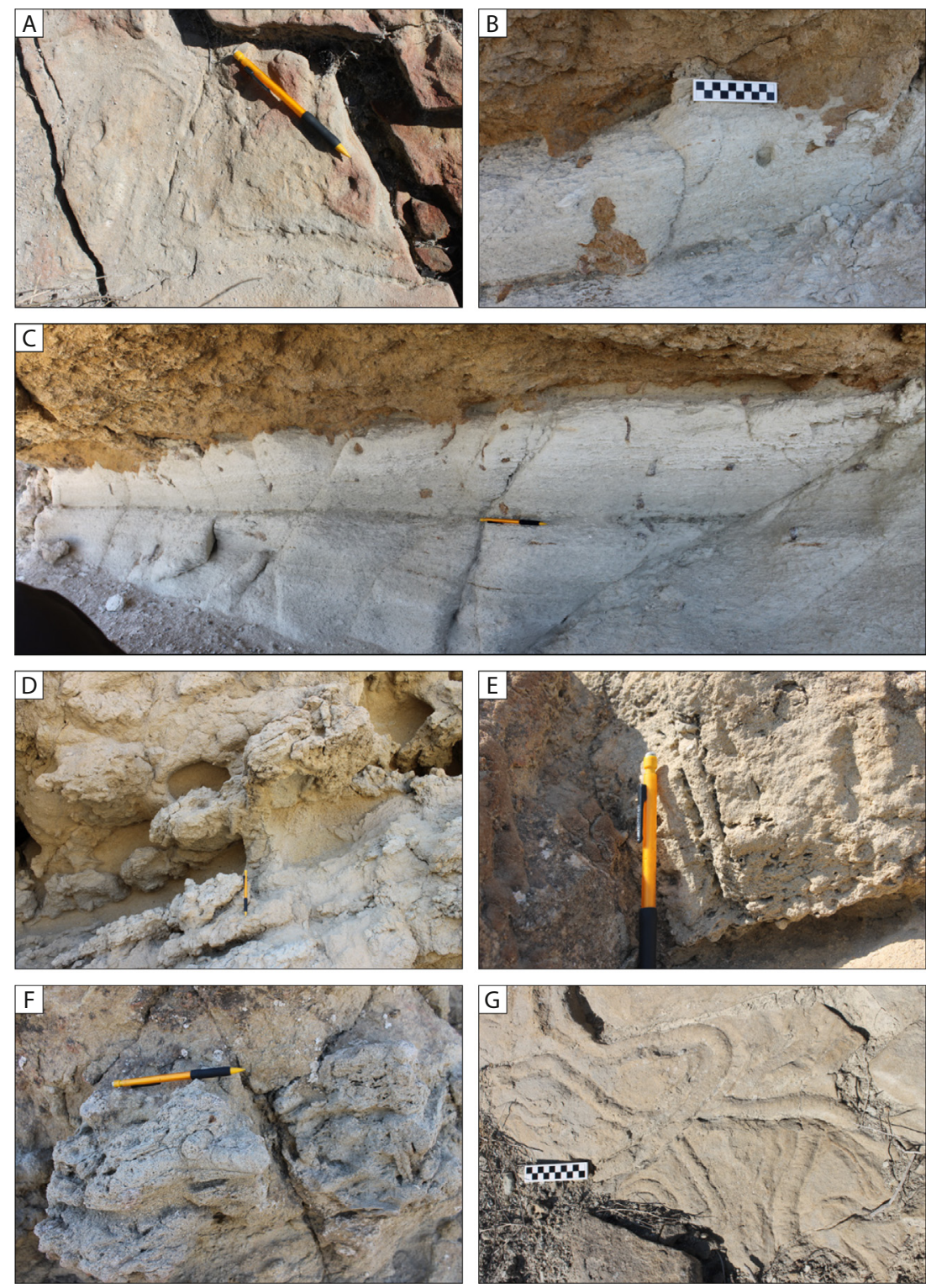

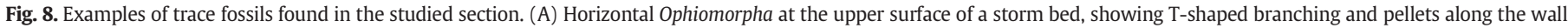

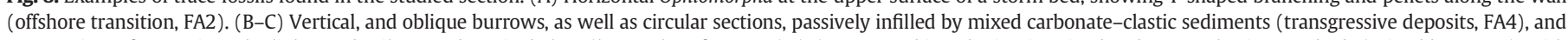

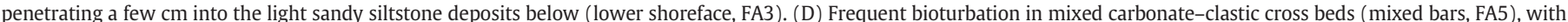

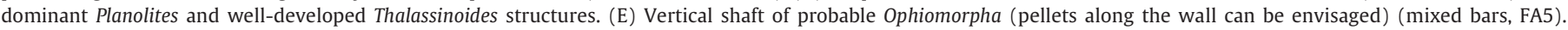

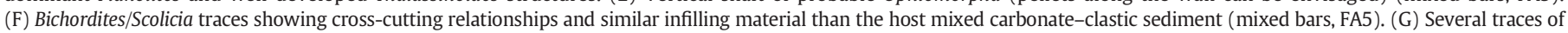
Scolicia showing cross-cutting relationships in the upper surface of a bioclastic sandstone bed (condensed section, FA6). 
preferentially in some areas of the seabed (as suggested by their lateral discontinuity), favouring a higher reworking by shelf currents.

\subsection{Highly bioturbated, concretionary sandstones (FA6 - condensed deposits)}

This facies association is composed by grey-yellow, intensely bioturbated sandstones (BI 5-6; Fig. 8G), with bioclasts accumulations (mainly bivalve fragments), occasional glauconitic grains, and often highly cemented or forming concretionary horizons (Fig. 4N, O). Traces include Scolicia showing cross-cutting relationships to bed top surfaces (Fig. 8G). Beds are generally thin (up to $20 \mathrm{~cm}$ ), but packages reach up to $1.5 \mathrm{~m}$ in thickness. They are often found conformably overlying lower shoreface deposits (FA3) or mixed bars (FA5), and overlain by offshore (FA1) or offshore transition (FA2) fine-grained deposits (Fig. 6).

\subsubsection{Interpretation}

The high bioturbation index of these deposits, with multiple generation of traces, together with the presence of bioclast accumulations and glauconitic grains and their concretionary/cemented nature is consistent with condensed deposits; these represent a considerable span of time recorded by only relatively thin layers, and form under low energy, low sedimentation rate conditions, associated with increased water depth during regional flooding events (Loutit et al., 1988).

\subsection{Erosive-based, bioclastic pebbly sandstones (FA7 - channel-fill)}

This facies association is composed of bioclastic, cross-bedded pebbly sandstones, contained in a concave-up erosive base, cutting several $\mathrm{cm}$ into the underlying deposits, and forming a $5 \mathrm{~m}$-thick package (Fig. 4L). The package is slightly fining-up, and contains a mix of skeletal fragments (dominantly bivalves, but also bryozoans and red algae), organic matter and large (up to several $\mathrm{cm}$-long) angular extraclasts (quartz and volcanic fragments), more concentrated towards the base (Fig. 4M). This facies association is only recognized in the upper part of the studied section, abruptly truncating lower shoreface deposits (FA3), and overlain by mixed bars (FA5) (Fig. 6).

\subsubsection{Interpretation}

The highly erosive, concave-up basal surface, together with the coarser nature and larger presence of landward material, mixed with reworked skeletal fragments, is consistent with these deposits being interpreted as subaqueous channel fills (Fig. 6).

\section{Stratigraphic arrangement}

The studied succession is summarized in Fig. 6. The succession shows an alternation of coarse and fine-grained mixed carbonate-siliciclastic deposits, which can be subdivided in at least 8 progradationalretrogradational cycles ( $\mathrm{C} 1-\mathrm{C} 8)$, each of them 23 to $45 \mathrm{~m}$-thick (Figs. 3, 5). Cycles start with either dominantly structureless to faintly laminated marlstones, with occasional thin-bedded sandstones, some with erosive bases and rippled tops (FA1 - offshore, Table 1, Fig. 4A), or with an alternation of laminated sandy marlstones and mediumbedded sandstones, with hummocky-cross stratification and common soft-sediment deformation (FA2 - offshore transition, Table 1, Fig. 4C, D). In some cycles (C1-3 and C7-8, Fig. 6), these are progressively replaced by coarsening-up packages of sandy mudstones to muddy sandstones, with wavy bedding and symmetrical ripple cross-lamination (FA3 - lower shoreface, Table 1, Fig. 4E). This progradational stacking culminates in some cycles ( $\mathrm{C} 1-2$, Fig. 6) with thin, intensely bioturbated sandstones (FA6 - condensed deposits, Table 1, Fig. 4N). In other cycles (C3-8, Fig. 6), it is abruptly truncated by erosive contacts bioturbated by large, sharp-walled burrows, passively infilled by overlying mixed carbonate-clastic sediments (FA4 - transgressive deposits, Table 1, Fig. $4 \mathrm{H}$ ), or in just one occasion by concave-up erosive surfaces, filled with bioclastic cross-bedded pebbly sandstones (FA6 - channel fill,
Table 1, Fig. 4L, M) (Fig. 6). These deposits are overlain by poorlyto moderately-sorted mixed carbonate-clastic units, rich in skeletal fragments and extraclasts (mainly quartz and volcanic fragments), and displaying large-scale sigmoidal cross bedding (FA5 - mixed bars, Table 1, Fig. 4I-K). They show a fining- and thinning-up arrangement, often capped by highly-cemented and concretionary bioturbated sandstones, with high ichnodiversity (FA6 - condensed deposits, Table 1, Fig. 4N), interpreted as containing maximum flooding surfaces.

\section{Depositional model}

The studied succession is interpreted to have deposited in a relatively shallow-water shelf (Fig. 9), around the storm-wave base, as suggested by the relative dominance of offshore transition deposits (FA2) with combined-flow structures (i.e., hummocky cross stratification) (Fig. 6). The fine-grained nature of the coarsening and thickening up successions of offshore (FA1), offshore transition (FA2) to lower shoreface (FA3) deposits (Fig. 6) suggests that there was a relatively distal coeval west- to north-westward prograding shoreline system (Fig. 10a). This shelf was only receiving occasional coarse-grained siliciclastic sediment supply (and organic debris) via forced regressions and/or seaward gravity flows (e.g. hyperpycnal flows), which underwent storm reworking during or shortly after deposition, and resulted in discrete $\mathrm{cm}$-thick sandstone beds within offshore transition deposits (Fig. 10b). After enough time to create a firm or compacted substrate, offshore transition to lower shoreface deposits were partially eroded during transgression, with the development of erosive and highly bioturbated ravinement surfaces (Fig. 10c), as suggested by the undeformed and sharp nature of the burrows (Fig. 8B, C) and their association to Glossifungites ichnofacies. These ravinement surfaces were followed by deposition of a relatively poorly-sorted assemblage of mixed deposits (FA4), dominated by skeletal fragments resulting from the remobilization of a coeval carbonate factory (Fig. 10d). The uneven accumulation of these mixed deposits on the seabed possibly resulted in areas that favoured higher reworking via shelf (most likely storm-wave) processes and nucleation of laterally extensive shelf ridges, with the development of sigmoidal cross-bedded barforms (FA5) (Fig. 10e). These show bidirectional accretion orientations (N$\mathrm{S}$ ), but dominantly pointing southward, at a high angle with respect to the dominantly west- to north-westward orientation of unidirectional palaeocurrents recorded from offshore-transition deposits (Fig. 9B). Continued transgression resulted in regional flooding, increased water depth and a decrease of reworking processes and deposition, leading to lower sedimentation rates and the development of highly biortubated, condensed deposits (FA7), containing maximum flooding surfaces (Fig. 10f). Finally, the next phase of advancement of the regressive shoreline system led to progressive deposition of fine-grained sediments in offshore and offshore-transition settings, resulting in the burial and effective preservation of the underlying mixed carbonate-siliciclastic shelf ridges (Fig. 10g).

\section{Discussion}

7.1. A fine-grained siliciclastic shelf and the origin of the remobilized carbonate factory

In the studied succession, the fine-grained, siliciclastic dominated offshore to lower shoreface deposits (FA1-FA3, Table 1) are abruptly truncated by mixed carbonate-siliciclastic units, through sharp, highly bioturbated transgressive ravinement surfaces. These mixed deposits are remarkably different from the underlying shelf deposits, with coarse-grained, bioclastic calcarenites (FA4, FA5, Table 1) with skeletal fragments. Because these skeletal fragments are only recognized in the mixed clastic-carbonate units (see Fig. 5), this implies the presence of a coeval carbonate factory, located in either (i) a more distal position 


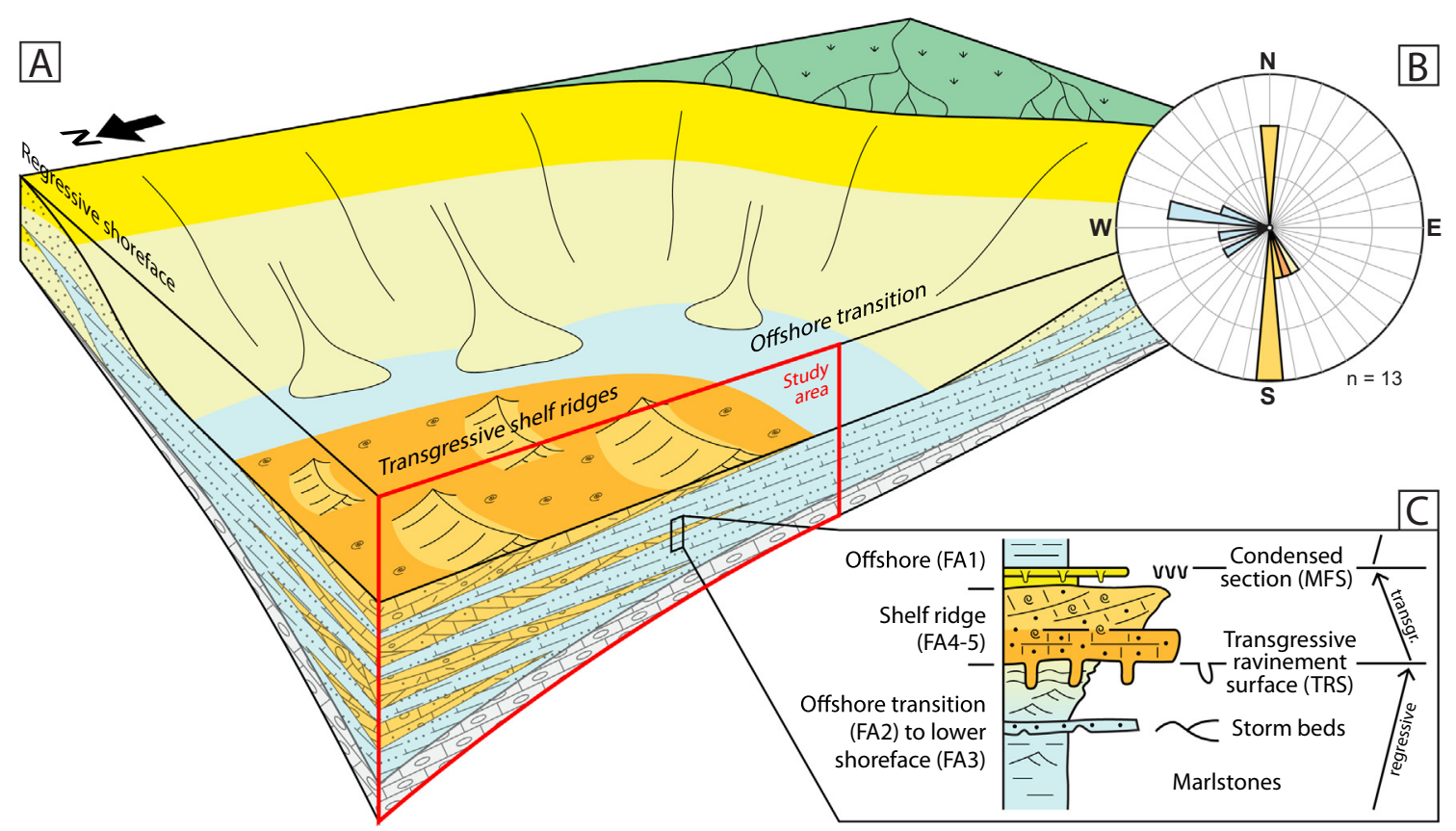

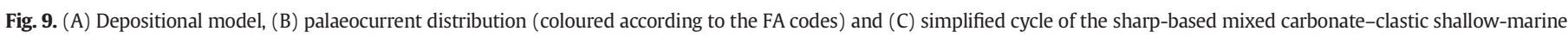

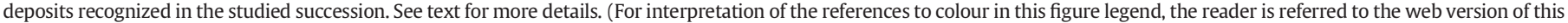
article.)

or (ii) a lateral position within the shelf. The occurrence of a bryomoltype skeletal association in the mixed deposits (mainly bryozoans and bivalves, and minor red algae and echinoids), would indicate non-tropical, temperate-type shallow-water conditions (Betzler et al., 1997). Because of the relative dominance of siliciclastic material of the studied mixed deposits it is not possible to reconstruct a biofacies belt model as described in other shallow-marine examples richer in carbonate skeletal-grains (e.g., late Miocene ramp of Menorca, Spain, Pomar et al., 2012). However, bryozoan-molluscechinoid associations have been reported as dominant in carbonate factories located at the proximal sector of the outer ramp (Brandano and Corda, 2002). This biota association is therefore characteristic of deeper depositional environments (i.e., aphotic zone in outer-middle ramp, Brandano and Corda, 2002) compared to other skeletal associations, like branching red algae-dominant (i.e., oligophotic zone - middle ramp) identified in other timeequivalent successions in the nearby Tabernas Basin (García-García et al., 2006b). This is therefore considered to favour the interpretation that the coeval carbonate factory supplying the skeletal fragments was located farther offshore, and remobilized during transgressions. The scenario where the carbonate factory is located in more distal positions relative to the equivalent shoreline supplying the siliciclastic fraction can occur quite commonly in mixed carbonate-siliciclastic shallow-marine systems (Schwarz et al., 2018; see also Reijmer, 2021).

\subsection{Poorly-sorted versus well-sorted shelf ridges}

Several of the mixed carbonate-siliciclastic deposits in the studied section are relatively poorly sorted and contain abundant extraclasts (mainly quartz and lithic fragments) and terrestrial organic matter fragments (Fig. 5). This contrasts with conventional transgressive shelf ridges, mostly composed of well-sorted sandstones (Cattaneo and Steel, 2003), particularly those undergoing long-term reworking/ remoulding during their migration along the shelf (Snedden and Dalrymple, 1999). The absence of an efficient segregation of heterolithic grains in the studied mixed shelf ridges is consistent with high-energy conditions induced by persistent storm-wave action. This is more characteristic around the shoreface zone than in more distal offshore settings (van Heteren et al., 2011; Rossi et al., 2017), where tidallymodulated segregation commonly occurs (Chiarella et al., 2012). The textural nature of the studied shelf ridges, more poorly-sorted and coarser-grained than conventional tidal-dominated offshore ridges, would therefore suggest that they developed around the shoreface zone, where sediment reworking by storm waves was common. The abundant extrabasinal detrital material derived from the high-energy storm reworking of (i) forced-regressive coarse-grained sandstones and (ii) sediment gravity-flow deposits, as extraclasts and terrestrial organic debris is commonly observed in sandstone beds within lower shoreface and offshore transition deposits (Fig. 5B). Additionally, welldeveloped burrowed ravinement basal surfaces and relatively short ridges (with single cross-bedding sets, and not forming compound bars) are more characteristic of gentle slopes and shallower-water settings (i.e., shoreface) (Nnafie et al., 2014).

Simulations of sand ridges with morphodynamic models conclude that the morphology and activity of sand ridges are controlled by the rate of sea-level rise, depth and coastal-shelf slope (Nnafie et al., 2014). Following those models, the shelf ridges studied here, with more common examples of single than compound barforms, would have been enhanced during low rates of sea-level rise on gentle coastal to inner shelf slopes. Marine transgressions represent common scenarios for the development of mixed carbonate-siliciclastic shelves (García-García et al., 2006b; Fontana et al., 2015; Salocchi et al., 2017), where the interplay of high-energy currents removing carbonate factories and coming from detrital input drowning emerged areas encourages the mixing of carbonate and siliciclastic grains (Longhitano et al., 2014).

\subsection{Implications for other studies of sharp-based shallow-marine deposits}

The sharp bases of the mixed carbonate-siliciclastic deposits studied here, assigned to the Glossifungites ichnofacies, have been associated with compacted, semi-lithified substrates, and interpreted as transgressive surfaces in other studies (Seilacher, 1967; MacEachern et al., 1992, 


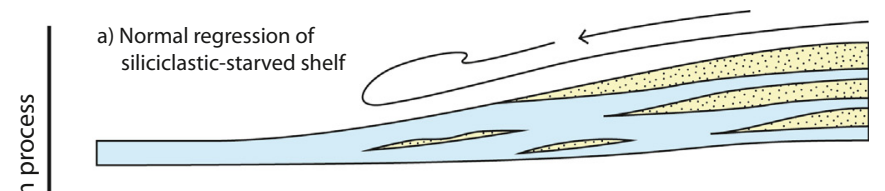

b) Deposition / reworking of hyperpicnites or forced regressive sandstone wedges

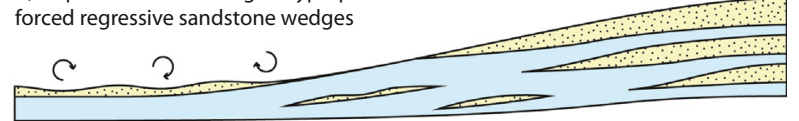

c) Transgressive ravinement erosion and bioturbation of semi-lithified seabed

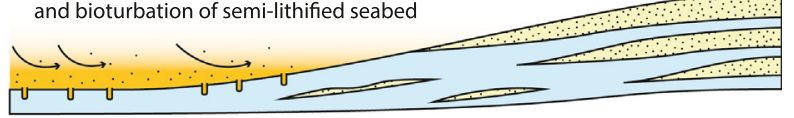

d) Remobilization of offshore carbonate factory and deposition of mixed deposits

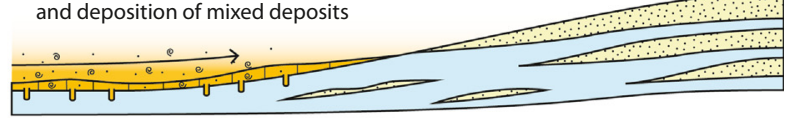

e) Reworking of mixed deposits

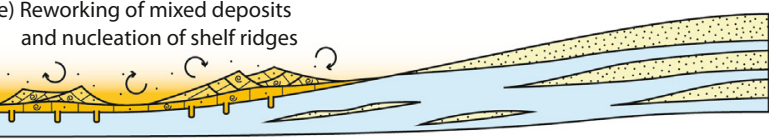

$\checkmark$

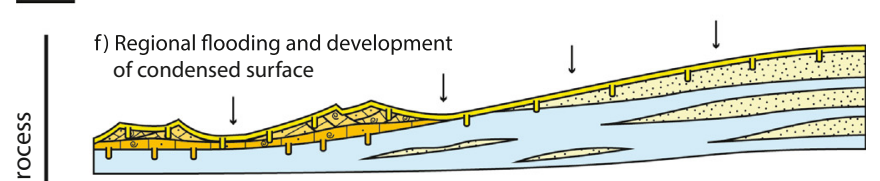

g) Renewed advancement of regressive shoreline, burial and preservation
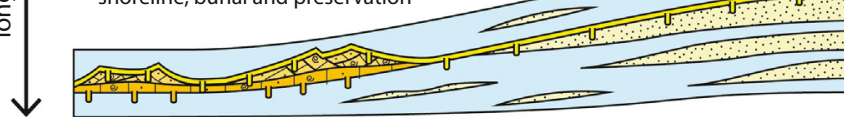

Fig. 10. Proposed evolutionary model for the development and preservation of sharpbased, mixed carbonate-clastic shallow-marine deposits, interpreted as transgressive shelf ridges. See text for a more detailed description of the different stages (a-f).

1999; Bann et al., 2004; Rodríguez-Tovar et al., 2007). This, combined with the presence of skeletal fragments from an offshore carbonate factory, significantly different from the underlying offshore transition to lower shoreface siliciclastic deposits, and the fining, thinning-up stacking of the deposits is consistent with these mixed units being interpreted as transgressive deposits (Fig. 9C). Several studies have proposed the sharp-based coarser-grained nature of some isolated shallow-marine deposits as criteria to interpret them as incised-valley fills or forced-regression sandstone wedges, associated with abrupt lowerings of relative sea-level (e.g. Hunt and Tucker, 1992; Ainsworth et al., 2000; Fitzsimmons and Johnson, 2000; Posamentier and Morris, 2000; García-García et al., 2011). These studies document significant grain-size breaks across sharp boundaries, but do not focus on significant compositional changes across major contacts. Therefore, our study emphasizes the importance of a careful analysis of the geometry and ichnology of sharp basal contacts in shallow-marine deposits, but also potential differential composition across their boundaries, and their stacking pattern, as key criteria to differentiate transgressive sharp-based mixed carbonate-siliciclastic deposits from their regressive counterparts. Adequately determining the correct depositional model for the development of sharp-based, shallow-marine deposits detached from their coeval coastline and encased in marine mudstones is critical as different interpretations may imply significant differences in their predicted reservoir performance (Snedden and Bergman, 1999; Cattaneo and Steel, 2003).
7.4. The influence of basin configuration in the upper Tortonian of the Betic Corridor

One of the most characteristic features of the studied succession is the repetition of offshore/shoreface siliciclastic- and shelf mixedlithofacies into 8 cycles ( $\mathrm{C} 1-8$, see Fig. 6). The consistency of the oscillation between similar depositional environments throughout the section suggests similar water depths and hydrodynamic regime persisted through time. A balanced accommodation/sediment supply ratio, with constant sediment supply and tectonic subsidence creating continuous accommodation space, would explain the preservation of such a thick, aggradational succession. However, other studies in relatively timeequivalent deposits in the southern margin of the Guadix Basin and in the northern margin of the Guadalquivir Foreland Basin have demonstrated the existence of coeval net regressive, siliciclastic-dominated shoreline systems (García-García et al., 2006a, 2021). These studies evidence the existence of a complex and dynamic basin configuration in the upper Tortonian, with the development of local depocentres and relatively narrow corridors or seaways during the connection between the Mediterranean and Atlantic (Martín et al., 2009; Reolid et al., 2012). This configuration resulted in intensification of bottom currents and favoured shelf reworking processes, as seen in this study and also in younger deposits (Betzler et al., 2006; García-García et al., 2009), and in the nearby Rifian corridor (Capella et al., 2017; de Weger et al., 2020; Beelen et al., 2021; Miguez-Salas et al., 2021). But it also promoted the development of local sediment entry points and variable stacking patterns, reflecting a differential interaction between active tectonics and sedimentation across the region (e.g., Andrić et al., 2018).

\section{Conclusions}

This study analyses and discusses the origin and development of sharp-based, mixed carbonate-siliciclastic shallow-marine deposits, with an outcrop example from the Upper Miocene of the Betic Cordillera (Spain). These mixed deposits abruptly truncate siliciclastic-dominated offshore to lower shoreface facies, via sharp, highly bioturbated contacts interpreted as transgressive ravinement surfaces, and form several mthick and hundreds of m-long depositional elements, interpreted as mixed carbonate-clastic shelf ridges. These ridges formed in a finegrained shelf which received occasional coarse siliciclastic supply via sediment gravity flows, but with a coeval offshore carbonate factory, eroded and remobilized during transgressions. Similar sharp-based shallow-marine deposits could be tentatively misinterpreted as forced-regressive wedges in other studies. However, this work provides criteria to distinguish them, including the nature of their lower contact, presence of reworked offshore skeletal fragments and their stacking pattern, which are consistent with their interpretation as transgressive deposits. When put in context with other studies in relatively timeequivalent regressive and more siliciclastic-dominated successions nearby, this evidences a complex configuration of the MediterraneanAtlantic connection during the upper Miocene, with sea corridors increasing currents and shelf reworking processes, and local sediment supplies and depocentres resulting in laterally variable stacking patterns, and reflecting differential and complex tectono-sedimentary interactions.

\section{Declaration of competing interest}

The authors declare that they have no known competing financial interests or personal relationships that could have appeared to influence the work reported in this paper.

\section{Acknowledgements}

This work was supported by Aker BP (ShelfSed project, University of Oslo) and Agencia Estatal de Investigación (AEI) y Fondo Europeo de 
Desarrollo Regional (FEDER) (CGL2017-89618-R project, University of Granada). The study by RT was funded by the project PID2019104625RB-100 (Secretaría de Estado de I+D+I, Spain), Research Group RNM-178 (Junta de Andalucía), B-RNM-072-UGR18 (FEDER Andalucía), and P18-RT-4074 (Junta de Andalucía), and the Scientific Excellence Unit UCE-2016-05 (Universidad de Granada). The study by JS was funded by the project PID2020-114381GB-100 (Secretaría de Estado de $\mathrm{I}+\mathrm{D}+\mathrm{I}$, Spain).

\section{References}

Ainsworth, R.B., Bosscher, H., Newall, M.J., 2000. Forward stratigraphic modelling of forced regressions: evidence for the genesis of attached and detached lowstand systems. In: Hunt, D., Gawthorpe, R.L. (Eds.), Sedimentary Response to Forced Regressions. Geological Society of London, Special Publicationvol. 172, pp. 163-176.

Andrić, N., Matenco, L., Hilgen, F., de Bresser, H., 2018. Structural controls on sedimentation during asymmetric extension: the case of Sorbas Basin (SE Spain). Global and Planetary Change 171, 185-206.

Balanyá, J.C., García-Dueñas, V., 1987. Les directions structurales dans le Domaine d'Alboran de part et d'outre du Detroit de Gibraltar. Comptes Rendus de l'Académie des Sciences 304, 929-933.

Bann, K.L., Fielding, C.R., MacEachern, J.A., Tye, S.C., 2004. Differentiation of estuarine and offshore marine deposits using integrated ichnology and sedimentology: Permian Pebbley Beach Formation, Sydney Basin, Australia. In: Mcllroy, D. (Ed.), The Application of Ichnology to Palaeoenvironmental and Stratigraphic Analysis. Geological Society of London, Special Publicationvol. 228, pp. 179-211.

Beelen, D., Wood, L., Najib Zaghloul, M., Haissen, F., Arts, M., Ouahbi, I., Redouane, M., Cardona, S., 2021. Tide-dominated deltas responding to high-frequency sea-level changes, pre-Messinian Rifian Corridor, Morocco. Journal of Sedimentary Research 90, 1642-1666.

Bergman, K.M., Walker, R.G., 1995. High-resolution sequence stratigraphic analysis of the Shannon sandstone in Wyoming, using a template for regional correlation. Journal of Sedimentary Research 2, 255-264.

Bergman, K., Walker, R.G., 1999. Campanian Shannon sandstone: an example of a falling stage systems tract deposit. In: Bergman, K.M., Snedden, J.W. (Eds.), Isolated Shallow Marine Sand Bodies: Sequence Stratigraphic Analysis and Sedimentologic Interpretation. SEPM Special Publicationvol. 64, pp. 85-93.

Berné, S., Lericolais, G., Marsset, T., Bourillet, J.F., De Batist, M., 1998. Erosional offshore sand ridges and lowstand shorefaces; examples from tide- and wave-dominated environments of France. Journal of Sedimentary Research 68, 540-555.

Betzler, C., Brachert, T.C., Braga, J.C., Martin, J.M., 1997. Nearshore, temperate, carbonate depositional systems (lower Tortonian, Agua Amarga Basin, southern Spain): implications for carbonate sequence stratigraphy. Sedimentary Geology 113, 27-53.

Betzler, C., Braga, J.C., Martín, J.M., Sanchez-Almazo, I.M., Lindhorst, S., 2006. Closure of a seaway: stratigraphic record and facies (Guadix basin, Southern Spain). International Journal of Earth Sciences 95, 903-910.

Bhattacharya, J.P., MacEachern, J.A., 2009. Hyperpycnal rivers and prodeltaic shelves in the Cretaceous seaway of North America. Journal of Sedimentary Research 79, 184-209.

Birgenheier, L.P., Horton, B., McCauley, A.D., Johnson, C.L., Kennedy, A., 2017. A depositional model for offshore deposits of the lower Blue Gate Member, Mancos Shale, Uinta Basin, Utah, USA. Sedimentology 64, 1402-1438.

Brandano, M. Corda, L, 2002. Nutrients, sea level and tectonics: constrains for the facies architecture of a Miocene carbonate ramp in central Italy. Terra Nova 14, 257-262.

Burton, J., Walker, R.G., 1999. Linear transgressive shoreface sandbodies controlled by fluctuations of relative sea level: Lower Cretaceous Viking Formation in the JoffreMikwan-Fenn area, Alberta, Canada. In: Bergman, K.M., Snedden, J.W. (Eds.), Isolated Shallow Marine Sand Bodies: Sequence Stratigraphic Analysis and Sedimentologic Interpretation. SEPM Special Publicationvol. 64, pp. 255-272.

Capella, W., Hernández-Molina, F.J., Flecker, R., Hilgen, F.J., Hssain, M., Kouwenhoven, T.J., Van Oorschot, M., Sierro, F.J., Stow, D.A.V., Trabucho-Alexandre, J., Tulbure, M.A., 2017. Sandy contourite drift in the late Miocene Rifian Corridor (Morocco): reconstruction of depositional environments in a foreland-basin seaway. Sedimentary Geology 355, 31-57.

Cattaneo, A., Steel, R.J., 2003. Transgressive deposits: a review of their variability. EarthScience Reviews 62, 187-228.

Chiarella, D., Longhitano, S.G., Sabato, L., Tropeano, M., 2012. Sedimentology and hydrodynamics of mixed (siliciclastic-bioclastic) shallow-marine deposits of Acerenza (Pliocene, Southern Apennines, Italy). Italian Journal of Geosciences 131, 136-151.

Chiarella, D., Longhitano, S.G., Mosdell, W., Telesca, D., 2020. Sedimentology and facies analysis of ancient sand ridges: Jurassic Rogn Formation, Trondelag Platform, offshore Norway. Marine and Petroleum Geology 112, 104082. https://doi.org/10.1111/sed. 12853.

de Weger, W., Hernández-Molina, F.J., Flecker, R., Sierro, F.J., Chiarella, D., Krijgsman, W., Manar, M.A., 2020. Late Miocene contourite channel system reveals intermittent overflow behavior. Geology 48, 1194-1199.

Desjardins, P.R., Buatois, L.A., Mangano, M.G., 2012. Tidal flats and subtidal sand bodies. In: Knaust, D., Bromley, R.G. (Eds.), Trace Fossils as Indicators of Sedimentary Environments. Developments in Sedimentologyvol. 64. Elsevier, Amsterdam, pp. 529-561.

Dott, R.H., Bourgois, J., 1982. Hummocky stratification: significance of its variable bedding sequences. Geological Society of America Bulletin 93, 663-668.
Duke, W.L., 1985. Hummocky cross-stratification, tropical hurricanes, and intense winter storms. Sedimentology 32, 167-194.

Duke, W.L., Arnott, R.W.C., Cheel, R.J., 1991. Shelf sandstones and hummocky crossstratification: new insights on a stormy debate. Geology 19, 625-628.

Dumas, S., Arnott, R.W.C., 2006. Origin of hummocky and swaley cross-stratification-the controlling influence of unidirectional current strength and aggradation rate. Geology 34, 1073-1076

Dumas, S., Arnott, R.W.C., Southard, J.B., 2005. Experiments on oscillatory-flow and combined-flow bed forms: implications for interpreting parts of the shallowmarine sedimentary record. Journal of Sedimentary Research 75, 501-513.

Dyer, K.R., Huntley, D.A., 1999. The origin, classification and modelling of sand banks and ridges. Continental Shelf Research 19, 1285-1330.

Fernández, J., Soria, J.M., Viseras, C., 1996. Stratigraphic architecture of the Neogene basins in the central sector of the Betic Cordillera (Spain): tectonic control and base level changes. In: Friend, P.F., Dabrio, C.J. (Eds.), Tertiary Basins of Spain: The Stratigraphic Record of Crustal Kinematics. Cambridge University Press, Cambridge, pp. 353-365.

Fitzsimmons, R., Johnson, S., 2000. Forced regressions: recognition, architecture and genesis in the Campanian of the Bighorn Basin, Wyoming. In: Hunt, D., Gawthorpe, R.L. (Eds.), Sedimentary Response to Forced RegressionsGeological Society of London, Special Publicationvol. 172, pp. 113-140.

Fontana, D., Conti, S., Fioroni, C., Grillenzoni, C., 2015. Factors controlling the evolution of a wedge-top temperate-type carbonate platform in the Miocene of the northern Apennines (Italy). Sedimentary Geology 319, 13-23.

García-García, F., Fernández, J., Viseras, C., Soria, J.M., 2006a. Architecture and sedimentary facies evolution in a delta stack controlled by fault growth (Betic Cordillera, southern Spain, late Tortonian). Sedimentary Geology 185, 79-92.

García-García, F., Fernández, J., Viseras, C., Soria, J.M., 2006b. High frequency cyclicity in a vertical alternation of Gilbert-type deltas and carbonate bioconstructions in the late Tortonian, Tabernas Basin, Southern Spain. Sedimentary Geology 192, 123-139.

García-García, F., Soria, J., Viseras, C., Fernández, J., 2009. High-frequency rhythmicity in a mixed siliciclastic-carbonate shelf (Late Miocene, Guadix Basin, Spain): a model of interplay between climatic oscillations, subsidence and sediment dispersal. Journal of Sedimentary Research 79, 302-315.

García-García, F., De Gea, G.A., Ruiz-Ortiz, P.A., 2011. Detached forced-regressive shoreface wedges at the Southern Iberian continental palaeomargin (Early Cretaceous, Betic Cordillera, S Spain). Sedimentary Geology 236, 197-210.

García-García, F., Rodríguez-Tovar, F.J., Poyatos-Moré, M., Yeste, L.M., Viseras, C., 2021. Sedimentological and ichnological signatures of an offshore-transitional hyperpycnal system (Upper Miocene, Betic Cordillera, southern Spain). Palaeogeography, Palaeoclimatology, Palaeoecology 561, 110039. https://doi.org/10.1016/j.palaeo.2020. 110039.

Harazim, D., McIlroy, D., 2015. Mud-rich density-driven flows along an Early Ordovician storm-dominated shoreline: implications for shallow-marine facies models. Journal of Sedimentary Research 85, 509-528.

Houbolt, J.J.H.C., 1968. Recent sediments in the Southern Bight of the North Sea. Geologie en Mijnbouw 47, 245-273.

Hunt, D., Tucker, M.E., 1992. Stranded parasequences and the forced regressive wedge systems tract: deposition during base-level'fall. Sedimentary Geology 81, 1-9.

Hüsing, S.K., Oms, O., Agustí, J., Garcés, M., Kouwenhoven, T.J., Krijgsman, W., Zachariasse, W.-J., 2010. On the late Miocene closure of the Mediterranean-Atlantic gateway through the Guadix basin (southern Spain). Palaeogeography Palaeoclimatology Palaeoecology 291, 167-179.

Jelby, M.E., Grundvåg, S.A., Helland-Hansen, W., Olaussen, S., Stemmerik, L., 2020. Tempestite facies variability and storm-depositional processes across a wide ramp: towards a polygenetic model for hummocky cross-stratification. Sedimentology 67, 742-781.

Jin, J.H., Chough, S.K., 2002. Erosional shelf ridges in the mid-eastern Yellow Sea. GeoMarine Letters 21, 219-225.

Johnson, H.D., Baldwin, C.T., 1996. Shallow clastic seas. In: Reading, H.G. (Ed.), Sedimentary Environments: Processes, Facies and Stratigraphy, 3rd edition Wiley-Blackwell, Oxford, pp. 232-280.

Kenyon, N.H., Belderon, R.H., Stride, A.H., Johnson, M.A., 1981. Offshore tidal sand-banks as indicators of net sand transport and as potential deposits. In: Nio, S.D., Shüttenhelm, R.T.E., Weering, Van, Tj., C.E. (Eds.), Holocene Marine Sedimentation in the North Sea Basin. IAS Special Publicationvol. 5, pp. 257-268.

Lamb, M.P., Myrow, P.M., Lukens, C., Houck, K., Strauss, J., 2008. Deposits from waveinfluenced turbidity currents: Pennsylvanian Minturn Formation, Colorado, USA. Journal of Sedimentary Research 78, 480-498.

Leszczynski, S., Nemec, W., 2019. Sedimentation in a synclinal shallow-marine embayment: Coniacian of the North Sudetic Synclinorium, SW Poland. Depositional Record 6, 144-171.

Leva-López, J., Rossi, V.M., Olariu, C., Steel, R.J., 2016. Architecture and recognition criteria of ancient shelf ridges; an example from Campanian Almond Formation in Hanna Basin, USA. Sedimentology 63, 1651-1676.

Longhitano, S.G., Mellere, D., Steel, R.J., Ainsworth, R.B., 2012. Tidal depositional systems in the rock record: a review and new insights. Sedimentary Geology 279, 2-22.

Longhitano, S.G., Chiarella, D., Muto, F., 2014. Three-dimensional to two-dimensional cross-trata transition in the lower Pleistocene Catanzaro tidal strait transgressive succession (southern Italy). Sedimentology 61, 2136-2171.

Longhitano, S.G., Rossi, V.M., Chiarella, D., Mellere, D., Tropeano, M., Dalrymple, R.W., Steel, R.J., Nappi, A., Olita, F. 2021. Anatomy of a mixed bioclastic-siliciclastic regressive tidal sand ridge: facies-based case study from the lower Pleistocene Siderno Strait, southern Italy. Sedimentology 68, 2293-2333.

Loutit, T.S., Hardenbol, J., Vail, P.R., Baum, G.R., 1988. Condensed sections: the key to agedating and correlation of continental margin sequences. In: Wilgus, C.K., Hastings, B. 
S., Kendall, C.G.St.C., Posamentier, H.W., Ross, C.A., Van Wagoner, J.C. (Eds.), Sea Level Changes - An Integrated Approach. SEPM Special Publicationvol. 42, pp. 183-213.

MacEachern, J.A., Raychaudhuri, I., Pemberton, S.G., 1992. Stratigraphic applications of the Glossifungites ichnofacies: delineating discontinuities in the rock record. In: Pemberton, S.G. (Ed.), Applications of Ichnology to Petroleum Exploration: A Core Workshop. SEPM Special Publication 17, Tulsa, OK, pp. 169-198.

MacEachern, J.A., Zaitlin, B.A., Pemberton, S.G., 1999. A sharp-based sandstone of the Viking Formation, Joffre Field, Alberta, Canada: criteria for recognition of transgressively incised shoreface complexes. Journal of Sedimentary Research 69, 876-892.

Martín, J.M., Braga, J.C., Aguirre, J., Puga-Bernabéu, Á., 2009. History and evolution of the North-Betic Strait (Prebetic Zone, Betic Cordillera): a narrow, early Tortonian, tidaldominated, Atlantic-Mediterranean marine passage. Sedimentary Geology 216, 80-90.

McBride, R.A., Moslow, T.F., 1991. Origin, evolution, and distribution of shoreface sand ridges, Atlantic inner shelf, USA. Marine Geology 97, 57-85.

Messina, C., Nemec, W., Martinius, A.W., Elfenbein, C., 2014. The Garn Formation (Bajocian-Bathonian) in the Kristin Field, Halten Terrace: its origin, facies architecture and primary heterogeneity model. In: Martinius, A.W., Ravnås, R., Howell, J.A. (Eds.), From Depositional Systems to Sedimentary Successions on the Norwegian Continental Margin. IAS Special Publicationvol. 46, pp. 513-550.

Michaud, K.J., Dalrymple, R.W., 2016. Facies, architecture and stratigraphic ocurrence of headland-attached tidal sand ridges in the Roda Formation, Northern Spain. In: Tessier, B., Raynaud, J.-Y. (Eds.), Contributions to Modern and Ancient Tidal Sedimentology: Proceedings of the Tidalites 2012 Conference. IAS Special Publicationvol. 47, pp. 313-341.

Miguez-Salas, O., Rodríguez-Tovar, F.J., de Weger, W., 2021. The Late Miocene Rifian corridor as a natural laboratory to explore a case of ichnofacies distribution in ancient gateways. Scientific Reports 11, 1-10.

Myrow, P.M., Fischer, W., Goodge, J.W., 2002. Wave-modified turbidites: combined-flow shoreline and shelf deposits, Cambrian, Antarctica. Journal of Sedimentary Research 72, 641-656.

Nnafie, A., Swart, H.E., Calvete, D., Garnier, R., 2014. Effects of sea level rise on the formation and drowning of shoreface-connected sand ridges, a model study. Continental Shelf Research 80, 32-48.

Olariu, M.I., Olariu, C., Steel, R.J., Dalrymple, R.W., Martinius, A.W., 2012. Anatomy of a laterally migrating tidal bar in front of a delta system: Esdolomada Member, Roda Formation, Tremp-Graus Basin, Spain. Sedimentology 59, 356-378.

Pattison, S.A., Ainsworth, R.B., Hoffman, T.A., 2007. Evidence of across-shelf transport of fine-grained sediments: turbidite-filled shelf channels in the Campanian Aberdeen Member, Book Cliffs, Utah, USA. Sedimentology 54, 1033-1064.

Pérez-Valera, F., Sánchez-Gómez, M., Pérez-López, A., Pérez-Valera, L.A., 2017. An evaporite-bearing accretionary complex in the northern front of the Betic-Rif orogen. Tectonics 36, 1006-1036.

Plint, A.G., 1988. Sharp-based shoreface sequences and 'offshore bars' in the Cardium Formation of Alberta: their relationship to relative changes in sea level. In: Wilgus, C.K., Hastings, B.S., Posamentier, H., Van Wagoner, J., Ross, C.A., Kendall, Ch.G.St.C. (Eds.), Sea-level Changes: An Integrated Approach. SEPM Special Publicationvol. 42, pp. 357-370.

Pomar, L., Bassant, P., Brandano, M., Ruchonnet, C., Janson, X., 2012. Impact of carbonate producing biota on platform architecture: insights from Miocene examples of the Mediterranean region. Earth-Science Reviews 113, 186-211.

Posamentier, H.W., 2002. Ancient shelf ridges-a potentially significant component of the transgressive systems tract: case study from offshore northwest Java. AAPG Bulletin $86,75-106$

Posamentier, H.W., Chamberlain, C.J., 1993. Sequence-stratigraphic analysis of Viking Formation lowstand beach deposits at Joarcam Field, Alberta, Canada. In: Posamentier, H. W., Summerhayes, C.P., Haq, B.U., Allen, G.P. (Eds.), Sequence Stratigraphy and Facies Associations. IAS Special Publicationvol. 18, pp. 469-485.

Posamentier, H.W., Morris, W.R., 2000. Aspects of the stratal architecture of forced regressive deposits. In: Hunt, D., Gawthorpe, R.L. (Eds.), Sedimentary Responses to Forced RegressionsGeological Society of London, Special Publicationvol. 172, pp. 19-46.

Reijmer, J.J.G., 2021. Marine carbonate factories: review and update. Sedimentology 68 1729-1796.

Reolid, M., García-García, F., Tomašových, A., Soria, J.M., 2012. Thick brachiopod shell concentrations from prodelta and siliciclastic ramp in a Tortonian AtlanticMediterranean strait (Miocene, Guadix Basin, southern Spain). Facies 58, 549-571.

Rodríguez-Tovar, F.J., Pérez-Valera, F., Pérez-López, A., 2007. Ichnological analysis in highresolution sequence stratigraphy: the Glossifungites ichnofacies in Triassic successions from the Betic Cordillera (southern Spain). Sedimentary Geology 198, 293-307.
Rossi, V.M., Longhitano, S.G., Mellere, D., Dalrymple, R.W., Steel, R.J., Chiarella, D., Olariu, C., 2017. Interplay of tidal and fluvial processes in an early Pleistocene, delta-fed, strait margin (Calabria, Southern Italy). Marine and Petroleum Geology 87, 14-30.

Salocchi, A.C., Argentino, C., Fontana, D., 2017. Evolution of a Miocene carbonate shelf (northern Apennines, Italy) revealed through a quantitative compositional study. Marine and Petroleum Geology 79, 340-350.

Schwarz, E., 2012. Sharp-based marine sandstone bodies in the Mulichinco Formation (Lower Cretaceous), Neuquén Basin, Argentina: remnants of transgressive offshore sand ridges. Sedimentology 59, 1478-1508.

Schwarz, E., Veiga, G.D., Trentini, G.A., Isla, M.F., Spaletti, L.A., 2018. Expanding the spectrum of shallow-marine, mixed carbonate-siliclastic systems: processes, facies distribution and depositional controls of a siliciclastic-dominated example. Sedimentology $65,1558-1589$

Seilacher, A., 1967. Bathymetry of trace fossils. Marine Geology 5, 413-428.

Snedden, J.W., Bergman, K., 1999. Isolated shallow marine sand bodies: deposits for all interpretations. In: Bergman, K.M., Snedden, J.W. (Eds.), Isolated Shallow Marine Sand Bodies: Sequence Stratigraphic Analysis and Sedimentologic Interpretation. SEPM Special Publicationvol. 64, pp. 1-11.

Snedden, J.W., Dalrymple, R.W., 1999. Modern shelf sand ridges: from historial perspective to a unified hydrohynamic and evolutionary model. In: Bergman, K.M., Snedden, J.W. (Eds.), Isolated Shallow Marine Sand Bodies: Sequence Stratigraphic Analysis and Sedimentologic Interpretation. SEPM Special Publicationvol. 64, pp. 13-28.

Snedden, J.W., Tillman, R.W., Culver, A.J., 2011. Genesis and evolution of a mid-shelf, storm-built sand ridge, New Jersey Continental Shelf, USA. Journal of Sedimentary Research 81, 534-552.

Soria, J.M., 1993. La sedimentación neógena entre Sierra Arana y el río Guadiana Menor. Evolución desde un margen continental hasta una cuenca intramontanosa. University of Granada, Spain (Ph.D. Thesis, 292 p.).

Soria, J.M., Fernández, J., Viseras, C., 1999. Late Miocene stratigraphy and palaeogeographic evolution of the intramontane Guadix Basin (Central Betic Cordillera, Spain): implications for an Atlantic-Mediterranean connection. Palaeogeography, Palaeoclimatology, Palaeoecology 151, 255-266.

Soria, J.M., Fernández, J., García, F., Viseras, C., 2003. Correlative lowstand deltaic and shelf systems in the Guadix Basin (Late Miocene, Betic Cordillera, Spain): the stratigraphic record of forced and normal regressions. Journal of Sedimentary Research 73, 912-925.

Steel, E., Simms, A.R., Steel, R., Olariu, C., 2018. Hyperpycnal delivery of sand to the continental shelf: Insights from the Jurassic Lajas Formation, Neuquén Basin, Argentina. Sedimentology 65, 2149-2170.

Stride, A.H., 1982. Offshore tidal deposits: sand sheet and sand bank facies. In: Stride, A.H. (Ed.), Offshore Tidal Sands. Springer, Dordrecht, pp. 95-125.

Suter, J.R., Clifton, E., 1999. The Shannon sandstone and isolated linear sand bodies: interpretations and realizations. In: Bergman, K.M., Snedden, J.W. (Eds.), Isolated Shallow Marine Sand Bodies: Sequence Stratigraphic Analysis and Sedimentologic Interpretation. SEPM Special Publicationvol. 64, pp. 321-356.

Swift, D.J.P., 1975. Tidal sand ridges and shoal-retreat massifs. Marine Geology 18 105-134.

Swift, D.J.P., Field, M.E., 1981. Evolution of a classic sand ridge field: Maryland sector North American inner shelf. Sedimentology 28, 461-482.

Taylor, A.M., Goldring, R., 1993. Description and analysis of bioturbation and ichnofabric. Journal of the Geological Society 150, 141-148.

Van de Meene, J.W.H., Boersma, J.R., Terwindt, J.H.J., 1996. Sedimentary structures of combined flow deposits from the shoreface-connected ridges along the central Dutch coast. Marine Geology 131, 151-175.

van Heteren, S., van der Spek, A., van der Valk, B., 2011. Evidence and implications of middle-to late-Holocene shoreface steepening offshore the western Netherlands. In: Rosati, J.D., Wang, P., Robberts, T. (Eds.), Proceedings of the Coastal Sediments, pp. 188-201 (2011).

Van Wagoner, J.C., 1991. High-frequency sequence stratigraphy and facies architecture of the Sego Sandstone in the Book Cliffs of Western Colorado and Eastern Utah. In: Van Wagoner, J.C., Jones, C.R., Taylor., D.R., Nummedal, D., Jennette, D.C., Riley, G.W. (Eds.), Sequence Stratigraphy Applications to Shelf Sandstone Reservoirs: Outcrop to Subsurface Examples. AAPG Special Publication25, pp. 15-42.

Walker, R.G., Plint, A.G., 1992. Wave- and storm-dominated shallow marine systems. In: Walker, R.G., James, N.P. (Eds.), Facies Models: Response to Sea Level Change. Geological Association of Canada, pp. 219-238.

Yang, B.C., Dalrymple, R.W., Chun, S.S., 2005. Sedimentation on a wave-dominated, opencoast tidal flat, south-western Korea: summer tidal flat - winter shoreface. Sedimentology 52, 235-252.

Zecchin, M., Catuneanu, O., Caffau, M., 2019. Wave-ravinement surfaces: classification and key characteristics. Earth-Science Reviews 188, 210-239. 